FREDERIC S. MISHKIN

University of Chicago

\title{
What Depressed the Consumer? The Household Balance Sheet and the 1973-75 Recession
}

THE RECESSION of 1973-75 was the most severe economic contraction in the postwar era. By the first quarter of 1975 , real gross national product had declined nearly 7 percent from its 1973 peak, about twice the decline in real GNP from peak to trough in 1957-58, the most severe previous postwar recession. Why was the recent recession so severe? What were the forces behind this sharp drop in aggregate demand?

One salient feature of the 1973-75 period was the unusually unfavorable shift in the balance-sheet position of American households. Recent theoretical and empirical research on the "life cycle" and "liquidity" hypotheses-both of which stress the importance of the consumer's balance-sheet position to consumer expenditure decisions ${ }^{1}$ - suggests that this might be an important contributor to the severity of the recession.

Note: I thank Jeff Perloff for encouraging me to pursue this line of research. Peter Temin and members of the Brookings panel provided useful comments, while Dave Modest was helpful in getting the MPS model up on the computer. The simulation results were generated using the Troll System, to which the National Bureau of Economic Research generously granted me access. Further research support has been provided by the Social Science Division Research Fund of the University of Chicago and the Social Science Research Council.

1. See Franco Modigliani, "Monetary Policy and Consumption: Linkages via Interest Rate and Wealth Effects in the FMP Model," in Consumer Spending and Monetary Policy: The Linkages, Proceedings of a Monetary Conference (Federal Reserve Bank of Boston, 1971), pp. 9-84; Frederic S. Mishkin, "Illiquidity, Consumer Durable Expenditure, and Monetary Policy," American Economic Review, 
Several issues arise in considering the possible effects of changes in household balance sheets on the economy. Does the timing of the changes indicate a causal effect on aggregate demand? Do estimated expenditure models for particular components of GNP that incorporate household balance-sheet effects explain the movements in the expenditure series for the 1973-75 period? How large might the effects of balance-sheet changes on aggregate demand have been in this recession? What role did the 1973-74 decline in the stock market play?

This paper is an attempt to answer these questions. Because other developments in the economy influence it, the balance sheet of American households must be viewed as endogenous. This paper is thus not intended to promote the view that balance-sheet changes "caused" the recession to be more severe than it otherwise would have been. Rather, it is an attempt to isolate the mechanisms through which restrictive policy and other events may have operated on the economy during 1973-75, and to improve the structural explanation of the cyclical movements of this period.

\section{Overview of the Household Balance Sheet: 1972-75}

In the absence of money illusion, the consumer would be concerned with his balance-sheet position in terms of the goods and services he could buy, and thus balance-sheet items that are deflated to real terms should be most relevant to consumer spending decisions. ${ }^{2}$ As pictured in figure 1 , which depicts the aggregate balance sheet of all American households in the 1972-75 period (1958 prices), household financial positions did undergo major shifts at critical points in the business cycle of this period.

Throughout 1972, the consumer's financial position improved steadily, and consumer expenditure was buoyant. Real net worth increased in every

vol. 66 (September 1976), pp. 642-54; J. R. Kearl and Frederic S. Mishkin, "Illiquidity, the Demand for Residential Housing, and Monetary Policy," Journal of Finance (forthcoming).

2. Throughout this paper real quantities are denoted in 1958 dollars. Also, because the recent revisions of the national income accounts are not compatible with the estimated equations from past work on the liquidity hypothesis or with the currently available version of the MIT-Penn-Social Science Research Council model, the unrevised data (which are described in the appendix) are used in the regressions and simulations here. 
Figure 1. Selected Components of the U.S. Household Balance Sheet, Beginning of Quarter, 1972-75

Billions of 1958 dollars

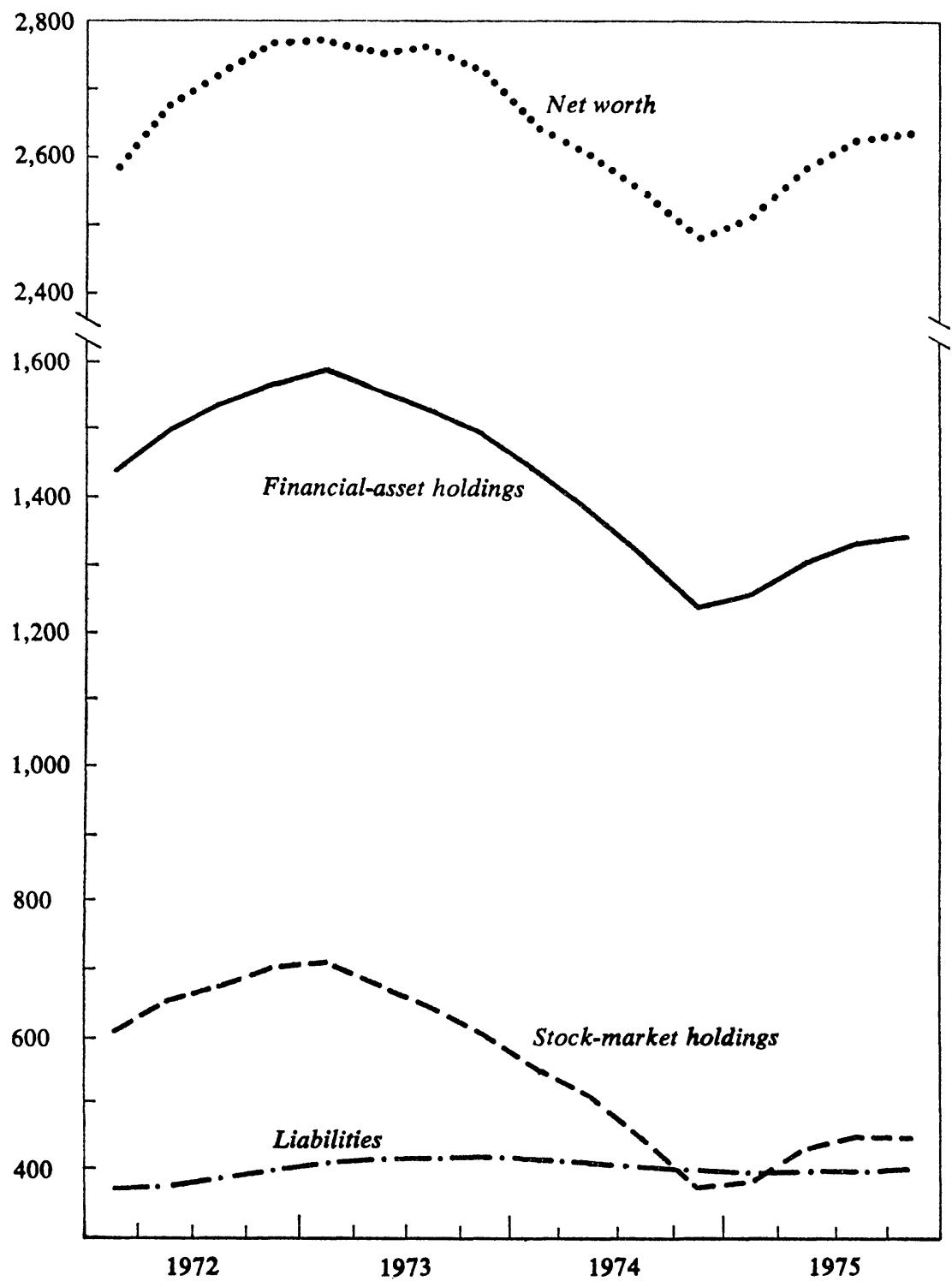

Source: Data supplied by the Board of Governors of the Federal Reserve System (described in "Quarterly Econometric Model Data Directory, January 1975"; MIT-Penn-SSRC; processed); deflated by the implicit consumption deflator of the MPS model. 
quarter, while the rise in household liabilities was matched by that in the real value of household financial assets. This favorable trend was reversed by the bear market in common stocks starting in early 1973 . While the consumer built up his liabilities to finance the booming purchases of consumer durables and housing, the drop in security prices led to a continuing decline in the real value of his financial assets and net worth. The household balance-sheet position deteriorated. This was followed by a decline in real consumer spending which helped initiate the recession starting in the fourth quarter of 1973.

By the end of 1974, consumer spending had collapsed, with the economy experiencing rates of personal saving that were virtually unprecedented in the postwar years. The bear market in common stocks had continued throughout 1974, causing a particularly acute deterioration in the aggregate financial position of households by the end of the year. Real holdings of financial assets and real net worth had shrunk 22 and 10 percent, respectively - the largest declines in the postwar period-whereas on average real financial assets and net worth grew at an annual rate of 3 to 5 percent in the postwar period.

Consumer spending picked up and the economy began to recover in 1975 as the aggregate household financial position took a turn for the better. Security prices advanced, and the real value of household financial assets and and real net worth began to rise from the low point at the beginning of the fourth quarter of 1974. A decline in the real burden of household indebtedness from the 1973:4 peak value enhanced this favorable trend.

The developments in the business cycle in 1973-75 and the changes in the balance-sheet position of American households suggest more than a coincidental relationship. The next sections will present evidence of a structural link between changes in household balance sheets and aggregate demand, and will provide quantitative estimates of how important these balance-sheet shifts were to the changes in aggregate demand in the 1973-75 recession. ${ }^{3}$

3. The 1973-75 recession is not the only period in which household balance sheets underwent major fluctuations, and thus could have had a significant impact on the business cycle. For an analysis of household balance-sheet effects during the Great Depression, see Frederic S. Mishkin, "The Household Balance-sheet and the Great Depression," Report 7639 (University of Chicago, Center for Mathematical Studies in Business and Economics, October 1976; processed). 


\section{Models of the Effects of Household Balance Sheets}

Two basic approaches to consumer behavior postulate that changes in the household balance sheet affect consumer spending decisions. The "life-cycle hypothesis of saving"4 of Modigliani-Brumberg and AndoModigliani concentrates on the consumer's consumption decisions (mostly with regard to nondurable goods and services), while the "liquidity" hypothesis, ${ }^{5}$ which I have advanced elsewhere, centers on the consumer's decision to acquire tangible assets such as consumer durables or housing.

\section{THE LIFE-CYCLE HYPOTHESIS}

In the life-cycle hypothesis, the consumer considers his lifetime resources in making consumption decisions. Individual consumption thus depends on the resources available to the consumer (his net worth plus the present value of his current and anticipated labor income-analogous to a permanent labor income concept), his age, and the rate of return on capital. In Modigliani's recent work, aggregation over all individuals in the economy leads to a consumption function in which total consumption, which includes expenditures on nondurable goods and services plus the rental value of the stock of consumer durables, is a function of current and past income ${ }^{6}$ and total net wealth.

4. See Franco Modigliani and Richard Brumberg, "Utility Analysis and the Consumption Function: An Interpretation of Cross-Section Data," in Kenneth K. Kurihara, ed., Post Keynesian Economics (Rutgers University Press, 1954), pp. 388-436; Modigliani, "Monetary Policy and Consumption"; and Albert Ando and Franco Modigliani, "The 'Life Cycle' Hypothesis of Saving: Aggregate Implications and Tests," American Economic Review, vol. 53 (March 1963, pt. 1), pp. 55-84.

5. See Mishkin, "Illiquidity, Consumer Durable Expenditure, and Monetary Policy."

6. The recent work of Robert E. Lucas, Jr., "Econometric Policy Evaluation: A Critique," in Karl Brunner and Allan H. Meltzer, eds., The Phillips Curve and Labor Markets, Carnegie-Rochester Conference Series on Public Policy, vol. 1 (Amsterdam: North-Holland, 1976), pp. 19-46, and empirical work by Robert E. Hall, "The Life Cycle-Permanent Income Hypothesis and the Role of Consumption in Aggregate Economic Activity" (Massachusetts Institute of Technology, Department of Economics, January 1977; processed) and by John F. O. Bilson and James E. Glassman, "A Consumption Function with Rational Forecasts of Permanent Income" (Northwestern University, April 1977; processed), show that using a fixed lagged structure on income to estimate permanent or expected income may prove to be misleading at times. Care must thus be taken in using the fixed lag coefficients to evaluate the response of the economy to tax changes. The same issue arises in the report by Franco Modigliani and Charles Steindel in this issue. 


$$
\frac{C O N}{N}=f\left(B(L) \frac{Y D}{N}, \frac{W}{N}\right) \text {, }
$$

where

$$
\begin{aligned}
C O N & =\text { real consumption } \\
Y D & =\text { real disposable income } \\
W & =\text { real household net worth } \\
B(L) & =\text { lag operator } \\
N & =\text { population. }
\end{aligned}
$$

An important component of the net-worth measure is household holdings of common stock. Capital gains or losses on these holdings may not be considered fully part of financial assets until they are realized. Movement in prices of common stock, which lead to unrealized capital gains or losses in the short run, should thus not have their full impact immediately. To reflect this, the net-wealth variable in equation 1 can be broken up into its stock and nonstock components, and household stock holdings can enter the equation with a distributed lag. ${ }^{7}$

The best-known empirical application of the life-cycle consumption function is that of the MIT-Penn-Social Science Research Council (MPS) model of the United States. The MPS consumption equation relates real per capita consumption, $C O N / N$ (again, 1958 dollars), to a twelvequarter distributed lag on per capita real disposable income, $Y D / N$, household real net worth per capita exclusive of corporate common stock, $(W-S T K) / N$, and an eight-quarter distributed lag on the per capita real value of household holdings of common stock, $S T K / N$. An additional constraint is imposed on the estimated equation: nonstock wealth is viewed as having the same long-run impact on consumption as stock wealth, and thus the coefficient on nonstock wealth is forced to equal the sum of the lag coefficients on stock holdings. ${ }^{8}$

7. The rationalization behind the distributed lag on stock-market wealth is somewhat arbitrary. Other possible rationalizations: consumers are slow to adjust to new information because of costs in adjusting their behavior, or they may view many changes in stock prices as temporary and thus will respond only to changes that persist.

Although the nonstock component of net wealth also has some accrued capital gains and losses, these are far less important to fluctuations in net wealth than are unrealized capital gains or losses on stock. This is the reason for the split between the stock and nonstock components of net wealth.

8. See the 1975 version of the MPS model, found in "Equations in the MITPenn-SSRC Econometric Model of the United States" (January 1975; processed). 
For purposes of this paper, this equation has been reestimated over the period 1954:1 to 1972:4 using instrumental variables with a correction for first-order serial correlation to produce consistent estimates, free of simultaneous-equations bias. ${ }^{9}$ As in the MPS equation, the distributed lags have been estimated with the lag coefficients constrained to lie on a seconddegree polynomial, with a constrained endpoint, and the equality of the long-run stock and nonstock coefficients has been imposed. Slightly better results were obtained when the distributed lag on stock holdings was taken to be seven quarters long rather than eight quarters, as in the MPS model, and the results with the seven-quarter lag are presented here. The reestimated consumption equation, with asymptotic $t$ statistics in parentheses and the coefficient on $u_{-1}$ equalling the first-order serial-correlation coefficient, appears below. ${ }^{10}$

$$
\begin{gathered}
\frac{C O N}{N}=\sum_{i=0}^{11} b_{i}\left(\frac{Y D}{N}\right)_{-i}+0.056\left(\frac{W-S T K}{N}\right) \\
+\sum_{i=0}^{6} c_{i}\left(\frac{S T K}{N}\right)_{-i}+0.738 u_{-1} . \\
\sum_{i=0}^{11} b_{i}=\underset{(17.6)}{0.659} \quad \sum_{i=0}^{6} c_{i}=\underset{(7.0)}{0.056 .} \\
R^{2}=0.9994 ; \text { Durbin-Watson }=2.03 ; \text { standard error }=0.007249 .
\end{gathered}
$$

Equation 2, whose parameters are very similar to those of the consumption equation most recently estimated for the MPS model, ${ }^{11}$ lends strong support to the view that changes in the household balance sheet have potent effects on consumption demand. The net-worth items enter very significantly in this regression; the sum of the lag coefficients (which

9. All the right-hand variables are taken to be endogenous. The list of instruments is as follows: the discount rate, unborrowed reserves plus currency outside of banks, exports, federal government expenditures, the personal income tax rate, these five variables lagged one period, the constant term, and population.

The estimation method developed by Ray C. Fair, "The Estimation of Simultaneous Equation Models with Lagged Endogenous Variables and First Order Serially Correlated Errors," Econometrica, vol. 38 (May 1970), pp. 507-16, has been used here with the appropriate additional instruments.

10. The lags on disposable income are as follows: $0.085,0.082,0.078,0.074$, $0.069,0.063,0.056,0.048,0.040,0.031,0.022,0.011$. The lags on holdings of common stock are: $0.017,0.013,0.010,0.007,0.005,0.003,0.001$.

11. See Barry Bosworth, "The Stock Market and the Economy," BPEA, 2:1975, p. 261 . 
is also equal to the coefficient on non-stock-market assets) has an asymptotic $t$ statistic of 7 . The equation indicates that net-wealth effects on consumption can indeed be sizable; a decline of $\$ 1$ of net worth leads to a fall of $5 \frac{1}{2} \phi$ in consumption.

\section{THE LIQUIDITY HYPOTHESIS}

In the work on the life-cycle hypothesis and in most other studies of wealth effects, the household portfolio is viewed as a homogeneous aggregate. The liquidity hypothesis differs in that it stresses the composition of the household balance sheet, in particular distinguishing between effects from consumer's financial assets and liabilities. ${ }^{12}$ Thus household liabilities are not netted out against other consumer assets in studying the impact of changes in household balance sheets on aggregate demand.

The liquidity hypothesis concentrates on the imperfect capital markets that cause certain tangible consumer assets, housing and consumer durables, to be highly illiquid; that is, the consumer incurs some loss when he tries to sell them (or to borrow against them) to raise cash, especially in an emergency. ${ }^{13} \mathrm{~A}$ consumer who suffers financial distress when he cannot readily pay his bills would prefer holding highly liquid financial assets rather than such illiquid tangible assets. In effect, the opportunity cost of holding consumer durables or housing increases substantially when a consumer gets into financial trouble. As the probability of financial distress increases, he will lower his demand for tangible assets.

The probability of suffering financial distress is affected by the composition of the consumer's balance sheet. When indebtedness is high, the consumer has large contractual payments for debt service, and possibly other financial obligations, that increase the likelihood of financial distress, thus decreasing the demand for tangible assets. When the value of his financial assets falls, the consumer is again more likely to suffer financial distress since his buffer against bad times has now diminished; this would also diminish the demand for tangible assets.

This analysis suggests that the consumer's desired holdings of durables and housing will be positively related to his initial holdings of financial

12. See Mishkin, "Illiquidity, Consumer Durable Expenditure, and Monetary Policy," for a more formal and detailed exposition.

13. Some intangible assets also have the illiquidity characteristic of tangible assets. Some types of term insurance would clearly fall into this category. 
assets and negatively related to his liabilities. ${ }^{14}$ An increase in indebtedness and a drop in holdings of financial assets, such as occurred in 1973, would raise the probability of financial distress, thus prompting the consumer to shift his demand away from durables and housing. ${ }^{15}$

The timing and duration of these effects are important issues. The effects from household balance sheets described above, as well as those operating through the life-cycle model, should be only temporary because consumers will adjust their portfolios to bring liabilities and assets to their desired levels over time; in equilibrium, liabilities and financial assets will be endogenously determined by the consumer along with the desired level of tangible assets and savings. Even so, these temporary effects may be extremely important when households are forced away from their desired portfolio positions by events outside of their control (such as movements in common stock prices, in income, in the general price level, in interest rates, and so on).

In two previous papers, consumer-durable and housing models that accord with the "liquidity" hypothesis have been estimated using data from postwar aggregate time series through the end of $1972 .{ }^{16}$ Housing and consumer durables are viewed as assets that yield a return in the form of consumption services; the consumer derives benefits from the services of the stock, not from the flow of durable purchases. The consumer thus has a desired stock of these tangible assets that is a function of the usual variables found in the literature-permanent income and a HallJorgenson rental cost of capital. ${ }^{17}$ The liquidity hypothesis indicates that, in addition, the desired stock of tangible assets is a function of the con-

14. The liquidity hypothesis also implies that the desired level of tangible assets is positively related to expected average (permanent) income and is negatively related to the consumer's perceptions of income variance. These results are not discussed here because they are not of central concern.

15. Usually, increases in debt are considered to be an indicator of consumer optimism and strong demand, yet the liquidity hypothesis indicates that a buildup of consumer indebtedness eventually proves to be a deterrent to future expenditure for tangible assets. This does not imply a contradiction; a rise in the stock of consumers' durable capital resulting from increased expenditure on consumer durables will deter future purchases of this type although the increased expenditure indicates consumer optimism as well.

16. Mishkin, "Illiquidity, Consumer Durable Expenditure, and Monetary Policy"; and Kearl and Mishkin, "Illiquidity."

17. Robert E. Hall and Dale W. Jorgenson, "Tax Policy and Investment Behavior," American Economic Review, vol. 57 (June 1967), pp. 391-414. 
sumer's debt and financial assets at the beginning of the period. Therefore,

$$
K^{*}=f\left(Y_{P}, C A P C, D E B T, F I N\right)+E_{A},
$$

where, as further elaborated in the appendix,

$K^{*}=$ desired stock of real tangible assets

$Y_{P}=$ expected real average (permanent) income, calculated as a fixed-weight distributed lag on past disposable income ${ }^{18}$

$C A P C=$ rental cost of capital $^{19}=(R+D)(P / P C O N)$

$R=$ interest rate $=$ Aaa corporate bond rate for durables and mortgage rate for housing

$D=$ annual depreciation rate $^{20}$

$P=$ implicit price deflator for the tangible asset $=$ the implicit price deflator for consumer durables $(P C D)$ for the durablegoods equation and the Census price deflator for single-family houses $(P H)$ for the housing equation

18. The series on permanent income has been constructed with a procedure outlined by Michael R. Darby, "The Allocation of Transitory Income Among Consumers' Assets," American Economic Review, vol. 62 (December 1972), pp. 939-40. The formula for calculating permanent income is:

where $Y D=$ disposable income and

$$
Y_{P}=\sum_{i=0}^{\infty} w_{i} Y D_{-i},
$$

$$
w_{i}=\gamma[(1+\beta)(1-\gamma)]^{i},
$$

where $\gamma=$ quarterly adjustment rate $=0.1$, and $\beta=$ quarterly growth rate of disposable income $=$ approximately 0.01 . For example, calculations of the first four lag coefficients are: $0.100,0.091,0.083$, and 0.075 .

19. The rental cost of capital used here is completely analogous to the rental cost of capital in the investment study of Hall and Jorgenson, "Tax Policy and Investment Behavior," and in Robert Hall's paper in this issue. The interest rate in the formula above is a nominal interest rate, not a real interest rate as would be appropriate in the Hall-Jorgenson formulation. Attempts were made to estimate the effect of inflation and include it in the model, yet experiments with varied distributed lags of past inflation proved fruitless: no significant effects could be obtained. On the one hand, with constant nominal interest rates, inflation lowers the rental cost of capital and encourages expenditures. On the other hand, evidence from consumer surveys indicates that inflation increases consumer perceptions of uncertainty (see $F$. Thomas Juster and Paul Wachtel, "Inflation and the Consumer," $B P E A, 1: 1972$, pp. 71-114), and this might have a depressing effect on purchases of tangible assets. J. R. Kearl also discusses why inflation might decrease housing purchases in "Inflation-Induced Distortions in the Real Economy: An Econometric and Simulation Study of Housing and Mortgage Innovation" (Ph.D. dissertation, Massachusetts Institute of Technology, 1975).

20. The annual depreciation rate used for consumer durables was 0.20 , while the rate used for single-family housing was 0.02 . 
$P C O N=$ implicit price deflator for total consumption

$D E B T=$ real household liabilities, beginning of quarter ${ }^{21}$

$F I N=$ real gross holdings of financial assets by households, beginning of quarter (includes demand deposits plus currency, time and savings deposits, bonds, corporate common stock, life insurance, pension funds, and other miscellaneous assets $)^{22}$

$E_{A}=$ additive error term.

Since a change in the rental cost of capital would be expected to have a larger absolute impact on the desired stock of the tangible asset when permanent income, and hence the desired stock, is high, the capital-cost measure is scaled by permanent income in linearizing equation 3 :

$$
K^{*}=a+(b+c C A P C) Y_{P}+d D E B T+e F I N+E_{A} .
$$

Expenditure is modeled using a stock-adjustment framework which views consumers as adjusting to their desired stock only slowly. The change in the stock (that is, net investment) is only a fraction, $\lambda$, of the gap between the desired and actual stock at the beginning of the period. Therefore,

$$
\left(K-K_{-1}\right)=\lambda\left(K^{*}-K_{-1}\right)+E_{B}
$$

where

$$
\begin{aligned}
K & =\text { real stock of the tangible assets, end of quarter } \\
\lambda & =\text { the quarterly adjustment rate } \\
E_{B} & =\text { additive error term, }
\end{aligned}
$$

and the numerical subscripts refer to the time period of the $K$ variable.

Expenditures, or equivalently gross investment, equals the sum of net investment and replacement. Assuming a quarterly replacement rate of $\delta$,

$$
E X P / 4=\delta K_{-1}+\left(K-K_{-1}\right),
$$

where $E X P$ is real expenditures at an annual rate. Combining equations 3 through 6,

$$
\begin{gathered}
E X P=4 \lambda a+(4 \lambda b+4 \lambda c C A P C) Y_{P}+4 \lambda d D E B T+4 \lambda e F I N \\
+4(\delta-\lambda) K_{-1}+u,
\end{gathered}
$$

where $u$ is an additive error term, which equals $4\left(\lambda E_{A}+E_{B}\right)$.

21. For housing, mortgage liabilities have been excluded from this measure. See Kearl and Mishkin, "Illiquidity," for an explanation.

22. For housing, equity in housing has been added to this measure. See ibid. 
The signs of all the coefficients of equation 7 are theoretically determined. The coefficient of permanent income should be positive because increased permanent income encourages expenditure on tangible assets. A higher rental cost of capital should discourage expenditure; this implies that $4 \lambda c$ is negative. The coefficient on the lagged stock term will be negative in the usual case in which the speed of adjustment is higher than the replacement rate.

The illiquidity of tangible assets should lead to a positive FIN coefficient and a negative $D E B T$ coefficient. Although the liquidity model does not imply that, for an individual, the debt coefficient should be markedly larger in absolute value than the financial-assets coefficient, this result might be expected in aggregate time-series estimates. Changes in the value of financial assets should have a smaller impact on expenditure of the wealthy, for whom liquidity is not a problem, than of the middle- or lowerincome groups. For this reason, the unequal and highly skewed distribution of financial assets in this country would tend to lower sharply the financial-assets coefficient in a model estimated on data from aggregate time-series. On the other hand, consumer-debt liabilities are distributed far more equally than financial assets; thus the coefficient on debt should have a high value in time-series estimations.

In addition, the estimated debt coefficient in equation 7 probably overstates the actual impact on expenditure from measured household liabilities. The theory behind the liquidity hypothesis indicates that any consumer obligation that requires a commitment to pay in the future, whether or not it is classified as a household liability, will deter expenditure on tangible assets. Consumer obligations excluded from household liabilities -lease payments, rent, contractual saving, insurance payments, education expenditures, and so on-should be highly correlated with the debt measure, since the same factors should affect the willingness to incur both these obligations and debt. Hence the debt variable might well be a proxy for these other consumer obligations, and the debt coefficient would reflect their influence as well as that of measured household liabilities.

Expenditures on Consumer Durables. The model of equation 7 has been estimated for real per capita expenditure on consumer durables with two modifications. Net investment in consumer durables is usually also viewed as a function of transitory income, and a transitory-income variable $\left(Y_{T}\right)$-which is simply current disposable income minus permanent income- has thus been added to the model of equation 7. Furthermore, as 
in the MPS consumption function, and as noted above, holdings of stockmarket assets are assumed to influence expenditure only with a distributed lag. The lag coefficients on stock-market assets were also constrained to lie on an endpoint-constrained second-degree polynomial, and the longrun equality of the stock-market and non-stock-market coefficients was imposed. The consumer-durable model was estimated with aggregate quarterly data over the period 1954-72 (described in the appendix), excluding six quarters that were affected by auto strikes in 1964 and 1970. Instrumental-variables estimation with a correction for first-order serial correlation (Fair's method) was used to avoid simultaneous-equations bias. $^{23}$ The estimation results, with the asymptotic $t$ statistics in parentheses, appear below. ${ }^{24}$ (All quantities are in 1958 dollars per capita and the $C D$ superscript refers to the consumer-durables sector.)

$$
\begin{aligned}
& \left.\frac{E X P^{C D}}{N}=\underset{(-3.30)}{-0.5239}+\underset{(2.94)}{0.2167} \frac{Y_{T}}{N}+\underset{(3.39)}{(0.7026}-\underset{(-3.25)}{0.6409} C A P C^{C D}\right) \frac{Y_{P}}{N} \\
& \underset{(-1.18)}{0.2630} \frac{K_{-1}^{C D}}{N} \underset{(-4.43)}{-0.3118} \frac{D E B T}{N}+0.0632\left(\frac{F I N-S T K}{N}\right) \\
& +\sum_{i=0}^{4} m_{i}\left(\frac{S T K}{N}\right)_{-i}+0.6383 u_{-1} \text {. } \\
& \sum_{i=0}^{4} m_{i}=\underset{(4.10)}{0.0632 .} \\
& R^{2}=0.9940 \text {; Durbin-Watson }=2.01 \text {; standard error }=0.007104 \text {. }
\end{aligned}
$$

The estimation results support the liquidity hypothesis that balancesheet changes have powerful effects on consumer-durable expenditure. ${ }^{25}$ The coefficients of the debt and financial-asset variables have the signs indicated by the liquidity hypothesis and are highly significant; the debt coefficient and the sum of the stock-market coefficients are over four times

23. The same estimation technique and instruments used in the equation 2 consumption function are used here. Again, all the right-hand variables are treated as endogenous.

24. The lag coefficients on $S T K / N$ were: $0.0231,0.0173,0.0121,0.0074$, and 0.0034 .

25. Estimates of this liquidity model for the categories of "nonauto" and "auto and parts" in consumer durables, found in Mishkin, "Illiquidity, Consumer Durable Expenditure, and Monetary Policy," are also quite encouraging and lend further support to this hypothesis. 
their respective standard errors. Furthermore, the other estimated parameters of the model have the expected signs, are usually significant, and have reasonable magnitudes. Of a $\$ 1$ increase in transitory income, $22 \phi$ is spent on consumer durables, while a permanent $\$ 1$ increase in income leads to a long-run increase of approximately $25 \phi$ in this kind of spending. ${ }^{26}$ At the means of the sample data, the short-run interest-rate elasticity of consumer-durable expenditure is -0.20 , while the price elasticity is -1.02. The lagged stock coefficient implies that over 12 percent of the discrepancy between desired and actual stocks is made up within the quarter-an annual adjustment rate of approximately 40 percent.

The depressing effect of debt holdings on purchases of consumer durables is quite substantial: for every dollar of liabilities held at the beginning of the quarter, the annual rate of durable purchases will drop by $31 \phi$ in the short run. Financial-asset holdings have a significant positive effect on the demand for durables, though it is not as strong as the depressing effect of debt; an extra dollar of such assets held at the beginning of the quarter leads to a $6.3 \phi$ increase in durable purchases in the short run.

Moreover, the decomposition of balance-sheet effects into their debt and financial-assets components is crucial to these significant findings. When net worth is separated into its stock-market and non-stock-market components as in equation 2 (but debt is netted against non-stock-market wealth), the estimated coefficient of wealth is only 0.0008 , with a trivial asymptotic $t$ statistic of 0.01 . Barry Bosworth similarly obtained statistically insignificant results from a net-wealth variable. ${ }^{27}$

Expenditures for Single-Family Homes. In applying the equation 7 model to housing demand, the real value of housing starts $(H S)$ was used as a proxy for consumer expenditures for housing since no appropriate direct data on these outlays are available. The equation was fitted to the real value per household of single-family housing starts over the 1956-72 period. As in the equations for consumer durables and consumption, estimation with instrumental variables with a correction for first-order serial

26. The permanent-income, transitory-income, and lagged-durable-stocks terms lead to a fairly complicated lag structure for income. A $\$ 1$ sustained increase in income leads to increased expenditure on consumer durables of $25 \phi$ in the initial quarter; the effect rises to a peak of $33 \phi$ in the eleventh quarter, and then declines to a long-run $25 \phi$.

27. Bosworth, "Stock Market and the Economy," pp. 265, 268. 
correlation was used to avoid simultaneous-equation bias. ${ }^{28}$ The estimation results, with asymptotic $t$ statistics in parentheses, are as follows: ${ }^{29}$

$$
\begin{aligned}
& \text { (9) } \left.\frac{H S^{S}}{H H}=\underset{(-0.12)}{-0.1108}+\underset{(3.61)}{(0.2028} \underset{(-3.87)}{-0.5240} C_{(A P C}\right) \frac{Y_{P}}{H H} \underset{(-3.40)}{-0.4438} \frac{D E B T}{H H} \\
& +\underset{\text { (4.27) }}{0.0322} \frac{F I N}{H H}-\underset{(-1.18)}{0.1348} \frac{K_{-1}^{S}}{H H}+0.5516 u_{-1} \text {, } \\
& R^{2}=0.8603 \text {; Durbin-Watson }=2.05 \text {; standard error }=0.01508 \text {. }
\end{aligned}
$$

where $H H$ is U.S. households, $H S^{S}$ is the real value of single-family housing starts, and $K^{S}$ is the stock of single-family housing.

The liquidity housing model is encouraging. All the coefficients in the

28. The basic set of instruments includes the discount rate, unborrowed reserves plus currency outside of banks, exports, federal government expenditures, the personal tax rate, the price of imports, the price of farm products, the constant term, and households. All the right-hand variables were treated as endogenous. Fair's method with the appropriate additional instruments was used in estimation.

29. Since illiquidity is a feature of a leased-as well as an owned-tangible asset, the liquidity model might be applied to leased assets such as multifamily housing $\left(H S^{M}\right)$. Estimation results for the multifamily liquidity model from Kearl and Mishkin, "Illiquidity," appear below.

$$
\begin{aligned}
& \frac{H S^{M}}{H H}=\underset{(-3.28)}{-0.7443}+\underset{(1.98)}{(0.1356-0.0340)}\left(-0.20 C^{M}\right) \frac{Y_{P}}{H H}-\underset{(-2.49)}{0.2554} \frac{D E B T}{H H} \\
& +\underset{\text { (3.09) }}{0.0223} \frac{F I N}{H H}-0.0840 \mathrm{~K}_{-1}^{M}+0.8654 u_{-1} \text {. }
\end{aligned}
$$

The numbers in parentheses are asymptotic $t$ statistics.

Although the debt and financial-assets variables have the appropriate signs and are significantly different from zero at the 5 percent level, these liquidity results are not robust when credit-rationing variables are added to the regression model.

Postsample tracking of the multifamily model also casts doubt on the usefulness of this equation. It severely overpredicts multifamily starts after 1973:3, and fails to predict the almost total collapse in multifamily construction, and its postsample tracking ability is worse than a multifamily housing model that excludes balance-sheet effects.

It is entirely possible that the liquidity variables are proxies for credit-rationing effects in the multifamily housing regressions. This is not altogether surprising, considering the speculative nature of the multifamily housing market, in which producers' decisions might be far more important to fluctuations in starts than is true for single-family housing. Moreover, this model does not incorporate the major institutional shifts that have taken place in this market as a result of rent control, the advent of real estate investment trusts, and the condominium boom. Further research dealing with these issues is certainly needed to clarify the major factors that influence fluctuations in multifamily construction. 
model are of the appropriate sign, and those of nonmortgage household liabilities and household holdings of financial assets are significantly different from zero at the 1 percent level. (As noted above, these variables differ somewhat from their counterparts in the consumer-durable model.) Unlike consumer durables, the financial-assets measure is not split up into its stock and nonstock components since experiments did not indicate the presence of a distributed lag in the impact of stock-market assets on housing starts. The balance-sheet effects are again substantial. A $\$ 1$ increase in nonmortgage household liabilities leads to a $44 \phi$ decline in the real value of housing starts in the short run while a $\$ 1$ increase in holdings of financial assets results in a $3.2 \phi$ short-run increase in the real value of housing starts. ${ }^{30} \mathrm{~A}$ permanent $\$ 1$ increase in income leads to a long-run increase in single-family housing starts of approximately $1 \phi$, and the shortrun interest elasticity is -0.94 . The lagged stock coefficients indicate that 15 percent of the gap between the desired and actual stock of single-family housing is made up within the year.

Credit rationing has been a central concern in housing research..$^{31}$ Not only the cost of credit but its availability is thought to be important in determining the level of housing activity. Researchers have used a number of proxies for the postulated effects of credit rationing, including deposit stocks or flows at thrift institutions, federal intermediary activity, changes in mortgage commitments, and the spread between short-term interest rates and the mortgage rate. Could the significant balance-sheet effects found in the housing model be spurious because the balance-sheet variables serve as proxies for credit-rationing effects? Experiments with various measures of credit rationing, reported in table 1 , indicate that balance-sheet effects are far more important to fluctuations in single-

30. If the more inclusive liabilities measure is used in these regressions-that is, if mortgages are not excluded from the debt measure-the debt coefficients in the single- and multifamily equations are only a third of the value reported above. With the more inclusive measure all the balance-sheet coefficients are still significant at the 5 percent level. The case for excluding mortgages from the debt measure in housing models seems reasonable, yet a case could also be made for using the more inclusive debt measure. The choice would not appreciably affect the macroeconomic implications of the housing equations, nor the results of this paper.

31. James Kearl, Kenneth Rosen, and Craig Swan, "Relationships Between the Mortgage Instruments, the Demand for Housing and Mortgage Credit: A Review of Empirical Studies," in Donald Lessard and Franco Modigliani, eds., New Mortgage Designs for Stable Housing in an Inflationary Environment, Proceedings of a Conference (Federal Reserve Bank of Boston, 1975), pp. 93-109. 
family housing starts than are credit-rationing effects. None of the creditrationing measures ever enters the housing model significantly, while the coefficients of the debt and financial-assets variables always remain significant and of the correct sign. These tests lend further support to the liquidity view for single-family housing.

\section{TRACKING THE RECENT RECESSION AND RECOVERY}

The validity and usefulness of including balance-sheet effects in the model presented above can be tested by comparing the postsample tracking ability of these models for 1973-76 with so-called "non-balancesheet" models that exclude such effects. The equations for consumption $(C O N)$, consumer durables $\left(E X P^{O D}\right)$, and housing $\left(H S^{S}\right)$ have been reestimated with the balance-sheet variables excluded. The results, using the same estimation techniques and sample periods as for the models presented previously, with the asymptotic $t$ statistics in parentheses, appear below. ${ }^{32}$

$$
\begin{gathered}
\frac{C O N}{N}=\sum_{i=0}^{11} b_{i}\left(\frac{Y D}{N}\right)_{-i}+0.9215 u_{-1} . \\
\sum_{i=0}^{11} b_{i}=0.927 . \\
(138.4)
\end{gathered}
$$

$R^{2}=0.991 ;$ Durbin-Watson $=1.97$; standard error $=0.008317$.

(11)

$$
\begin{gathered}
\left.\frac{E X P^{C D}}{N}=\underset{(-1.52)}{-0.2205}+\underset{(2.01)}{0.1954} \frac{Y_{T}}{N}+\underset{(2.39)}{(0.4611}-0.7982 C A P C^{C D}\right) \frac{Y_{P}}{N} \\
-0.0535) \frac{K_{-1}^{C D}}{N}+0.7846 u_{-1} .
\end{gathered}
$$

$$
\begin{aligned}
& R^{2}=0.9919 \text {; Durbin-Watson }=1.75 \text {; standard error }=0.008111 \text {. } \\
& \begin{array}{c}
\frac{H S^{S}}{H H}=\underset{(5.19)}{2.6481}+\underset{(4.15)}{\left(0.1111-0.8084 C A P C^{S}\right) \frac{Y_{P}}{H H}} \\
-0.4135 \frac{K_{-1}^{S}}{H H}+0.7638 u_{-1 \cdot} .
\end{array} \\
& R^{2}=0.8571 \text {; Durbin-Watson }=2.04 \text {; standard error }=0.015008 \text {. }
\end{aligned}
$$

Figures 2 through 4 compare the postsample tracking of the balance-

32. The instruments used in estimation are the same as those for the corresponding models presented earlier. 


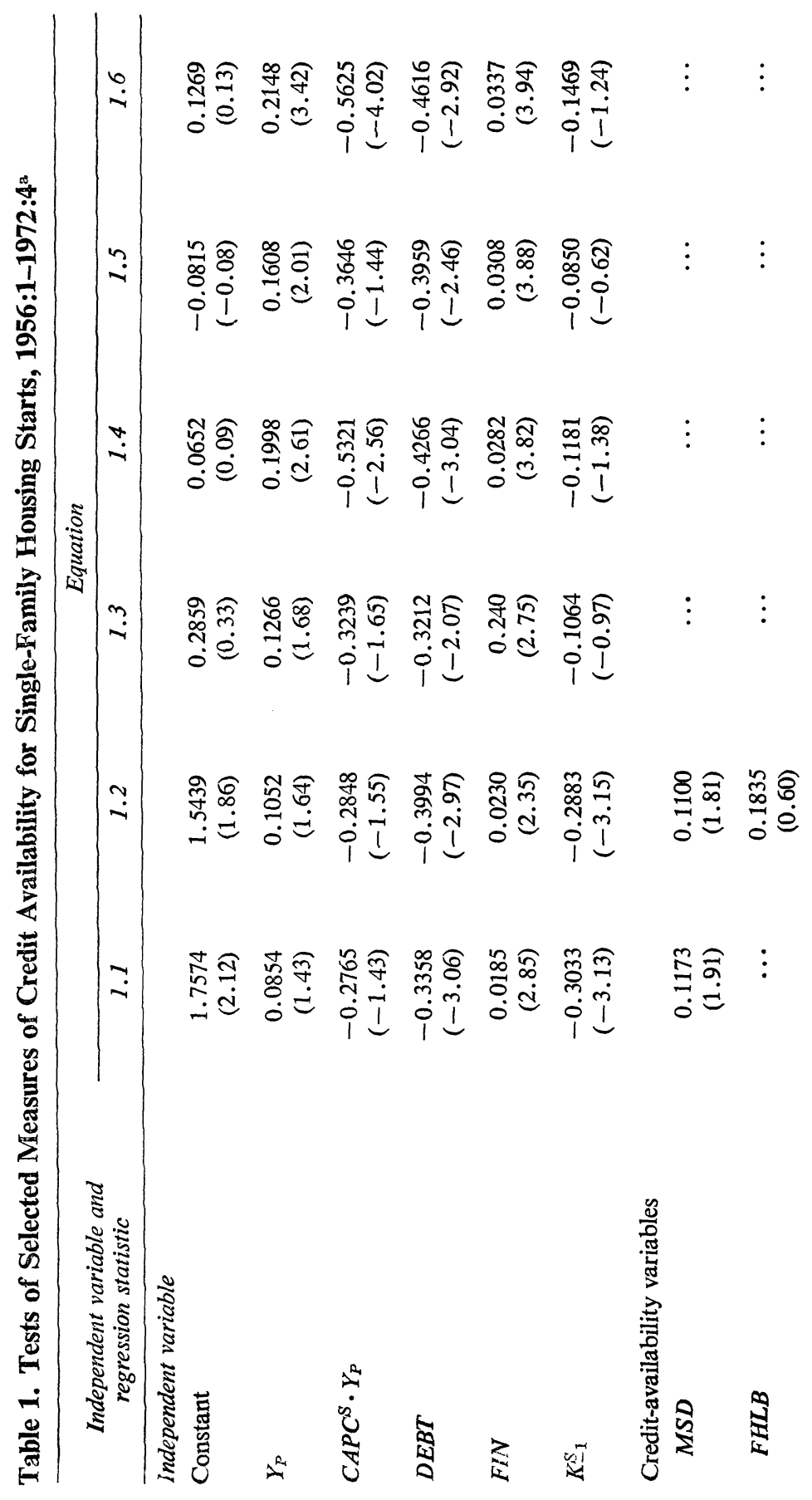




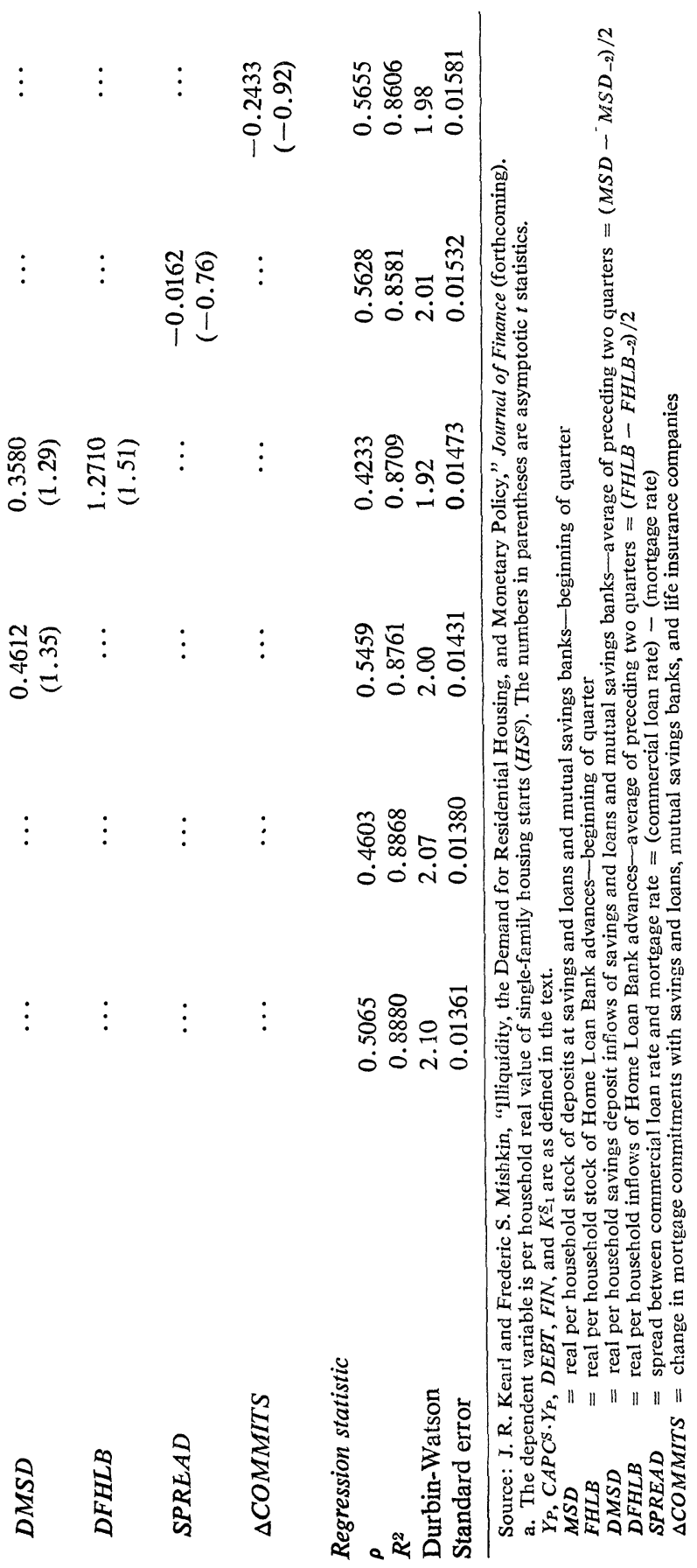


Figure 2. Postsample Predictions from Balance-Sheet Life-Cycle and Non-Balance-Sheet Consumption Models, Quarterly, 1973:1-1976:3 Billions of 1958 dollars

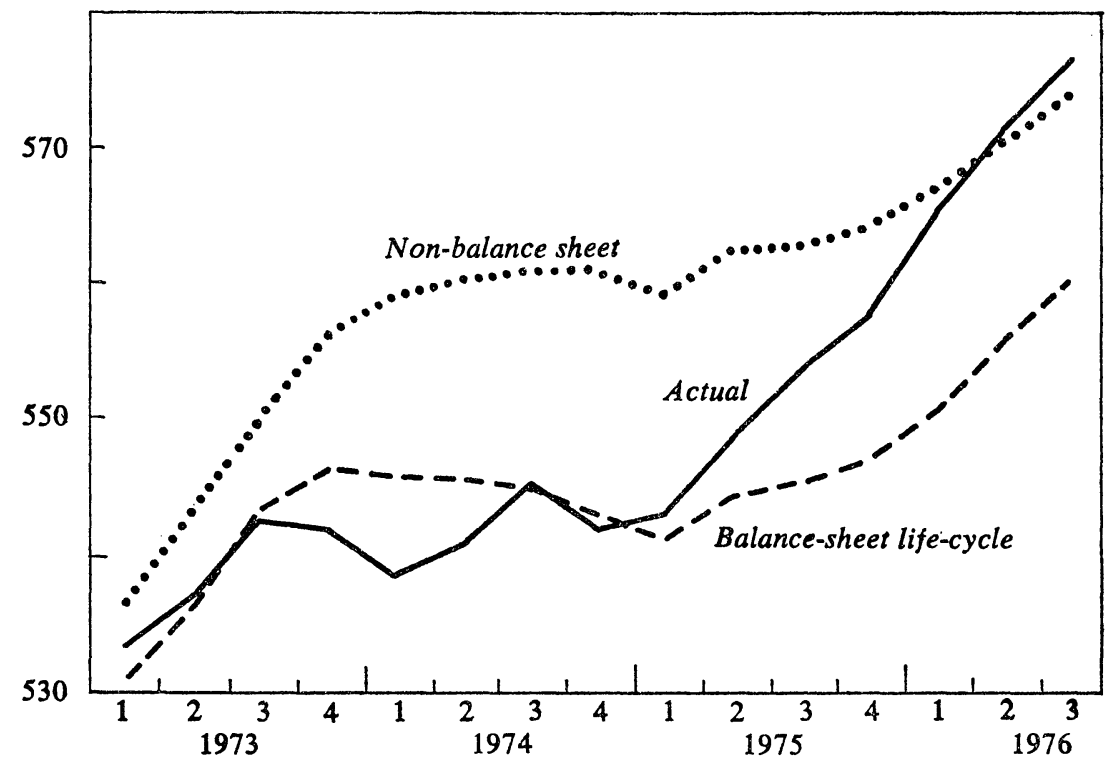

Sources: Predicted-derived from text equations 2 and 10;a ctual-1973:1-1975:3, MPS data bank; later quarters were constructed using the rate of change of the revised data of the U.S. Department of Commerce to extrapolate the unrevised data.

sheet models with that of the other models. The predictions have been generated with historical data and with no correction for serial correlation. ${ }^{33}$

The balance-sheet life-cycle consumption function performs well in the contraction phase of the recession. It tracks the sluggishness in consumption demand after the third quarter of 1973 and does not systematically under- or overpredict consumption in this period. The non-balancesheet consumption equation does not perform as well in the contraction phase. It grossly overpredicts consumption in late 1973 and 1974. Al-

33. The data used here for the quarters 1975:4-1976:3 were constructed by using the rate of change of the new, revised data of the U.S. Department of Commerce to extrapolate the unrevised data through 1976:3.

Postsample dynamic simulations of the consumer-durable and housing models, balance-sheet and non-balance-sheet, in which the lagged stock term is treated as endogenous, yield results similar to those in the text. 
Figure 3. Postsample Predictions from Liquidity and Non-Balance-Sheet Consumer-Durable Models, Quarterly, 1973:1-1976:3

Billions of 1958 dollars

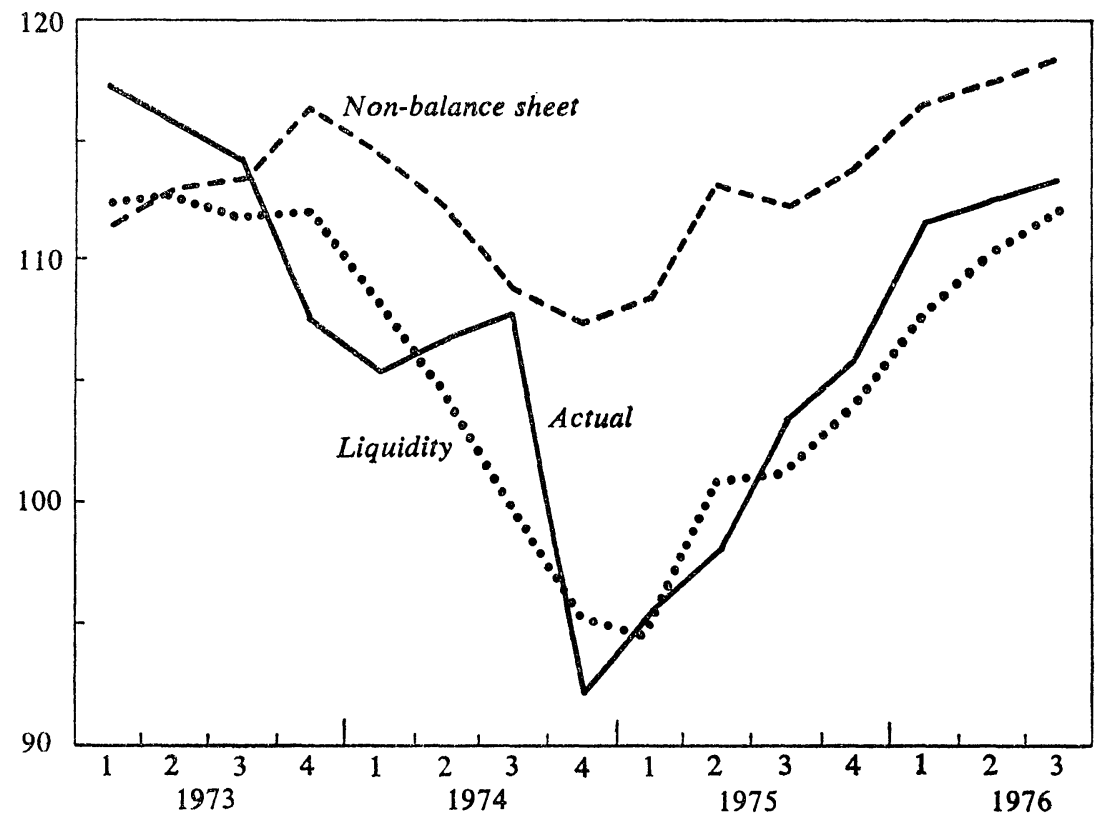

Source: Predicted--derived from text equations 8 and 11 ; actual-same as figure 2.

though the balance-sheet equation indicates an upturn in consumption in 1975 and 1976, it underpredicts the rise in consumption in the recovery period. Still, it outperforms the non-balance-sheet equation model for the whole period by a wide margin; it has a root mean-square error (RMSE) for the 1973-76 period of $\$ 8.2$ billion, a third less than the $\$ 12.4$ billion RMSE for the non-balance-sheet equation.

The liquidity consumer-durable model tracks well in both recession and recovery during the 1973-76 period. It captures almost the entire collapse in consumer-durable expenditure from the peak in 1973:1 and is within one quarter of catching the 1973:1 and 1974:4 turning points of the series. It also nicely tracks the $\$ 20$ billion (1958 prices, as always) upturn in expenditures for consumer durables in 1975 and 1976, and displays no systematic under- or overprediction (see figure 3 ). When balance-sheet items are excluded, the ability to predict consumer-durable expenditure is far inferior: the turning point in 1973:1 is completely 
Figure 4. Postsample Predictions from Liquidity and Non-Balance-Sheet Models for Single-Family Housing, 1973:1-1976:3

\section{Billions of 1958 dollars}

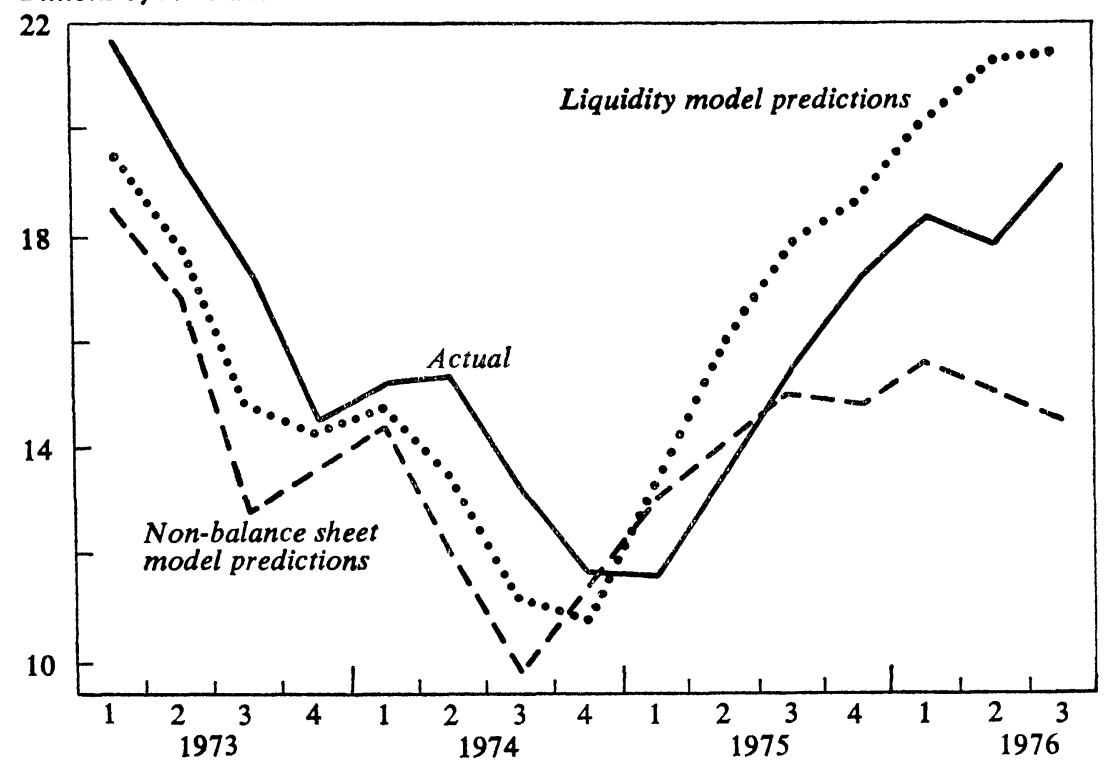

Source: Predicted-derived from text equations 9 and 12; actual-see the appendix.

missed, a severe overprediction occurs after the third quarter of 1973, and the 20 percent decline from $1973: 1$ to $1974: 4$ is not tracked at all. The $\$ 8.5$ billion RMSE for 1973-76 of the non-balance-sheet model is well over double the $\$ 3.5$ billion RMSE of the liquidity model.

As shown in figure 4, the liquidity model tracks the drop of over 40 percent in single-family housing starts, and misses the 1975:1 turning point by only one quarter. The strength of demand for single-family housing in 1975 and 1976 is also well predicted. Although it tracks reasonably well during the 1973-75 period, the non-balance-sheet, singlefamily housing model does not perform as well. Furthermore, it does not track the upturn in starts with much precision, for it indicates a weakening in 1976 that never materialized. The liquidity model's RMSE for $1973-76$ of $\$ 1.9$ billion is almost a third less than the non-balance-sheet model's RMSE of $\$ 2.7$ billion.

The evidence presented here indicates that the life-cycle model of con- 
sumption and the liquidity models for consumer durables and singlefamily housing have good tracking records outside the period of sample fit. The performance of the liquidity models of consumer durables and singlefamily housing-which use estimated coefficients unaltered from their previously published values-is particularly impressive since both the downturn and upturn in the series are accurately tracked. Postsample prediction ability in this period should be a fairly stringent test of the usefulness of including household balance-sheet effects in models for these sectors.

\section{THREE FURTHER ISSUES}

The balance-sheet effects that show up in equations 2,8 , and 9 would be suspect if they are misspecified. First, these effects may be proxies for current-income effects that are suppressed because the long polynomial distributed lags in income weight current income inadequately. ${ }^{34}$ Second, the constraint that household holdings of stock-market assets have the same long-run effect on demand as other types of assets do may not be empirically valid, and its imposition may affect the estimates of stockmarket effects. ${ }^{35}$ Finally, a problem arises because the use of a distributed lag on household holdings of stock-market assets-a practice without strong theoretical justification-may be responsible for the appearance of balance-sheet effects.

Current-Income Effect. The first issue, that balance-sheet effects may be a proxy for an understated current-income effect, is a problem only for the consumption equation. In the case of consumer durables, current income is entered directly in the equation through the transitory-income variable, the difference between current disposable income and permanent income. Since permanent income is an explanatory variable, the model used for estimation purposes is exactly equivalent to one in which current disposable income replaces transitory income. If transitory income is added to the regression models for housing, its coefficient is always in-

34. See the Wharton model for an example of models with shorter income lags and larger current-income effects. It is described in Michael D. McCarthy, The Wharton Quarterly Econometric Forecasting Model Mark III (University of Pennsylvania, Economics Research Unit, 1972).

35. Bosworth, "Stock Market and the Economy." 
significant and negative-the wrong sign-whether or not balance-sheet variables are included..$^{36}$ These results agree with those of other researchers, who do not find a significant effect of current income, independent of permanent income, on housing demand. ${ }^{37}$

Table 2 deals with the current-income issue for the consumption equation. To test whether the long polynomial distributed lag on income gives insufficient weight to current income and thereby results in significant wealth coefficients, current disposable income per capita has been added to the model of equation 2. Current income does not enter significantly into this regression, thus casting doubt on the proposition that the currentincome effect is understated in the life-cycle consumption equation. In addition, entering an unrestricted variable for current disposable income into the consumption regression does not appreciably change the wealth effect, nor does it reduce its statistical significance. To see whether the distributed lag on income is too long and thus results in significant wealth effects, equation 2 has been run with lags of varying lengths that have not been restricted to lie on a second-order polynomial. This unrestricted form allows the greatest flexibility for the income coefficients, and permits the most general test of the effect of choosing a particular distributed-lag form for income. In all cases the coefficient $(S T K / N)$ on overall wealth remains significant at the 1 percent level and retains its high value. A deterioration in fit becomes increasingly apparent as the income lag is shortened, while the autocorrelation coefficient-often a measure of misspecification -rises as the lag drops below twelve quarters. The evidence suggests that a twelve-quarter lag on disposable income does not lead to a gross misspecification of income effects, and that the effect of wealth on consumption remains strong regardless of the income lag chosen.

Although the life-cycle model implies that a constant term should not be included in the consumption regressions, one has been added in several cases as a test. In all these cases, the wealth effects remain statistically significant at the 1 percent level. For example, when a constant term is added to the third equation in table 2 the drop in the total wealth effect is less than 10 percent; the constant term is insignificant at the 5 percent level; and the added current-income variable is still insignificantly different from zero.

36. The asymptotic $t$ statistics are always less than 1.6 in absolute value.

37. See Kearl and others, "Relationships Between the Mortgage Instruments, the Demand for Housing and Mortgage Credit." 


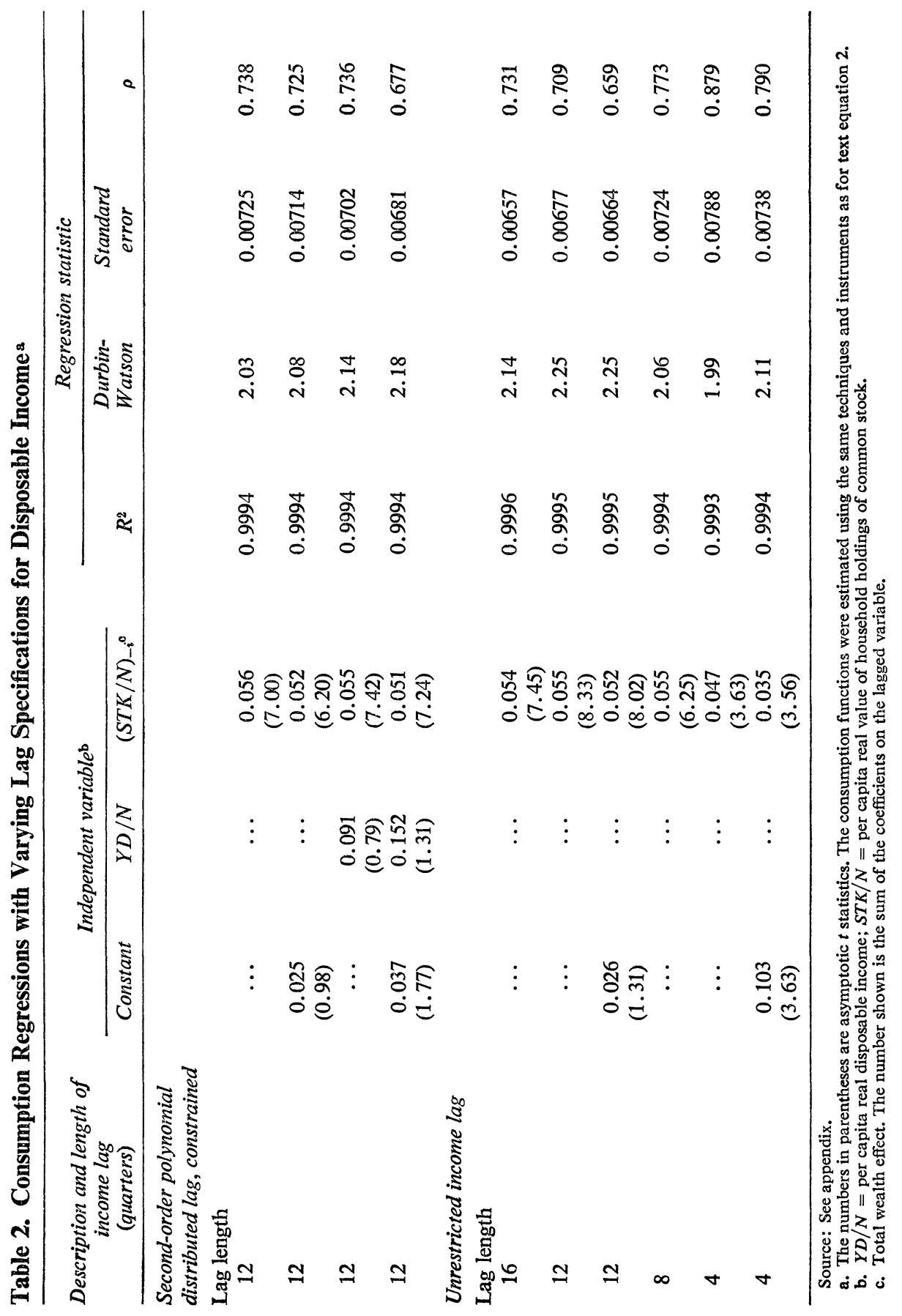




\section{ASSETS CONSTRAINT}

For the "assets constraint" to be valid in aggregate equations, the responses to changes in balance sheets should not differ much between the wealthy, who hold the bulk of equities, and the less well-to-do, who hold much of their wealth in tangible assets and savings accounts. Furthermore, as Barry Bosworth has recently pointed out, changes in the value of assets that result from changes in interest rates, as is often the case for common stocks, will not have the same impact on expenditure as changes in the value of assets due to other events: the income and substitution effects are quite different. Thus changes in the value of stock-market assets might not have the same effect on demand as changes in households' savings deposits and the like. Is the assets constraint empirically valid? And, how different are estimates of balance-sheet effects as a result of the imposition of this constraint?

Tests designed to answer that question for the balance-sheet models of consumption, consumer durables, and housing can be found in tables 3 and 4. In none of these regressions can the assets constraint be rejected at the 5 percent level of significance, nor does relaxation of this constraint eliminate balance-sheet effects operating through the stock market. For consumption, stock-market effects do decline slightly when the assets constraint is not imposed: the sum of the coefficients on stock-market assets drops approximately 18 percent. In the regressions of the liquidity model, stock-market effects change by less than 10 percent when the assets constraint is not imposed, and are sometimes lower when it is. In the liquidity regressions, because the measure of nonstock assets has very little variation around its trend rate of growth, the coefficient on nonstock assets is estimated with great imprecision, as evidenced by the small asymptotic $t$ statistics. Results on the effects of nonstock assets neither support nor reject the liquidity hypothesis. The assets constraint has been imposed in the earlier liquidity regressions, 8 and 9 , simply because this results in more sensible equations.

Imposition of the assets constraint does not appear to be empirically unwarranted, and it leaves intact most of the stock-market effects operating through the household balance sheet.

Distributed Lags. Tables 3 and 4 also contain estimates of household balance-sheet effects when all the balance-sheet variables enter the model 


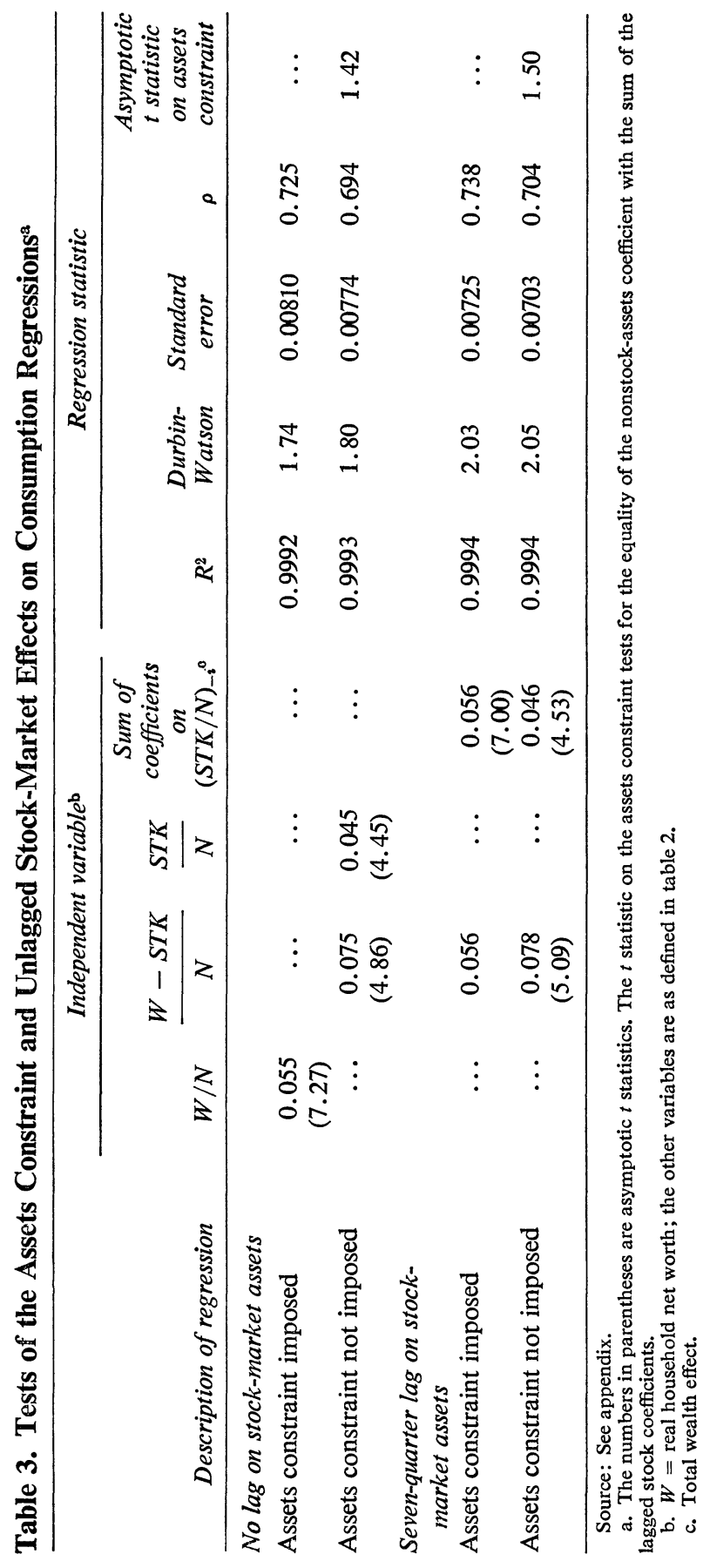




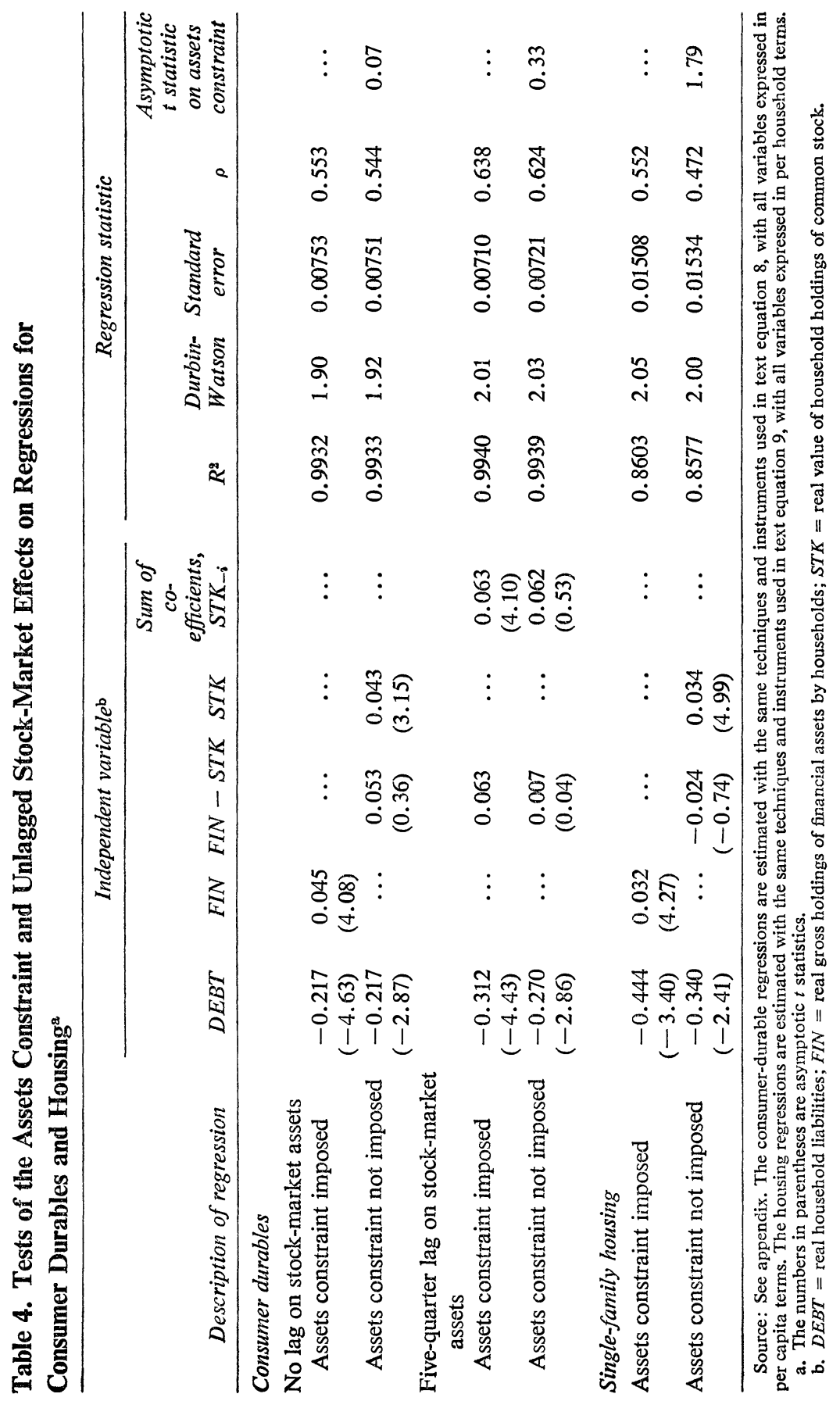


without distributed lags. In these cases, the household balance-sheet effects still remain powerful and statistically significant. ${ }^{38}$

\section{The 1973-75 Recession}

The theories and empirical work described above indicate the channels through which shifts in household balance sheets could have affected aggregate demand in the 1973-75 recession. In fact, household financial positions did undergo a radical deterioration during that period, and could supply a partial explanation for its severity. The deterioration in household balance sheets that began early in 1973 and became particularly serious by the end of 1974 may have depressed consumption because consumers' lifetime resources had diminished. Furthermore, consumers found themselves in a weaker financial position. Coupled with increased uncertainty, this weakening may have turned them away from purchases of illiquid assets such as consumer durables and housing because the possible loss from holding them had increased along with the probability of financial distress. Only with the improvement in financial position in 1975 did consumers return to the marketplace to spur expenditures on consumption goods and housing demand.

This story seems plausible, yet the question still remains, how important were these balance-sheet effects in the economic downturn?

To attempt to answer these questions, I have used dynamic simulations with the estimated life-cycle and liquidity equations-equations 2,8 , and 9. Estimates of household balance-sheet effects on aggregate demand can be derived by comparing simulations of a hypothetical system, in which these effects have been suppressed for the 1973-75 period, to "control" simulations in which they are present. ${ }^{39}$ In the control simulations, the residuals (the difference between the fitted and actual values of the depen-

38. The index of consumer sentiment compiled by the Survey Research Center and a filtered version of this index (Juster and Wachtel, "Inflation and the Consumer") have been added to liquidity-model regressions for consumer durables and housing. These sentiment variables are never significant, while the debt and financialassets coefficients still retain their appropriate signs and continue to be statistically significant. Results reported in Modigliani, "Monetary Policy and Consumption," also indicate that balance-sheet effects do not disappear and become statistically insignificant when sentiment variables are included in consumption regressions.

39. This is a standard simulation technique. For one application, see ibid. nomics, vol. 1 (September 1974), pp. 245-302. 
dent variable) are fed back into the equation, and the household balancesheet items are allowed to take on their historical values. These control simulations will thus track the historical data exactly in the 1973-75 period. In simulations in which balance-sheet effects are suppressed, the control residuals are again fed back into the equations-thus insuring that effects other than those from balance sheets still operate-and the balance-sheet items (in real terms) of each equation are allowed to trend from the 1972:4 value using growth rates calculated from the five-year period 1967:4 to 1972:4. ${ }^{40}$ This technique freezes out balance-sheet effects on any equation for the 1973-75 period. The difference between results from these hypothetical simulations and from the control simulations provides measures of the impact of balance-sheet shifts on demand. ${ }^{41}$

One possible way of proceeding would be to undertake simulation experiments in which the liquidity and life-cycle equations have been embedded in a macroeconometric model, and, using the techniques discussed above, derive the overall household balance-sheet effects on the economy during the 1973-75 period. This procedure presents the thorny problem of choosing a particular macroeconometric model from the many available alternatives. Because, at present, there is no agreed-upon "best" macroeconometric model, a different approach seems warranted. First, dynamic simulation experiments with only the life-cycle and liquidity equations are used to derive estimates of household balance-sheet effects. These estimates, which have been generated without a general-equilibrium, macroeconometric model, will reflect only direct, partial effects, and not multiplier-accelerator, feedback interactions from the rest of the economy on the consumption and housing sectors. Even though these estimates will thus understate the overall balance-sheet effects, they have the distinct advantage of being independent of the properties of a particular macro model. Full-system simulations with such a model-in this case, the 1975

40. The annual growth rates used to calculate the trend values of the balancesheet items (in real terms) are as follows: household liabilities, 4.1 percent; household mortgages, 3.5 percent; nonstock net wealth, 3.5 percent; nonstock financial assets, 3.1 percent; and stock-market assets, 4.1 percent.

41. It is somewhat difficult to isolate the effects of one factor in the economy if it interacts with other factors in a simultaneous system. Thus in some sense the simulation experiments of this section are artificial, because balance-sheet effects are suppressed without acknowledging that this would affect other behavioral relations. Nonetheless, these experiments are useful, for they are one way of getting at the questions posed in the text. 
Table 5. Direct, Partial Effects of Household Balance Sheets on Aggregate Demand in Selected Sectors, 1973:1-1975:3

Billions of 1958 dollars

\begin{tabular}{cccc}
\hline Year and quarter & Consumption & $\begin{array}{c}\text { Consumer } \\
\text { durable } \\
\text { expenditures }\end{array}$ & $\begin{array}{c}\text { Value of } \\
\text { single-family } \\
\text { housing starts }\end{array}$ \\
\hline $1973: 1$ & -1.5 & -1.4 & -1.3 \\
2 & -2.7 & -2.8 & -2.5 \\
3 & -2.3 & -4.4 & -3.2 \\
4 & -5.5 & -6.7 & -4.2 \\
$1974: 1$ & -10.4 & -7.6 & -4.2 \\
2 & -13.8 & -8.4 & -3.5 \\
3 & -17.4 & -9.9 & -3.9 \\
4 & -21.8 & -12.1 & -4.6 \\
$1975: 1$ & -24.8 & -12.9 & -3.0 \\
2 & -25.2 & -11.8 & -0.3 \\
3 & -25.3 & -9.7 & 1.8 \\
\hline
\end{tabular}

Sources: Results from dynamic simulations starting in 1973:1 using text equations 2, 8, and 9. Only the lagged stock terms in text equations 8 and 9 are treated as endogenous. The lagged stock terms are generated from a perpetual-inventory equation (used in generating the stock series in the first place) using the simulated values from the previous period. The table above gives estimates of the difference between control simulations in which the residuals have been fed back into the models so that the models track the actual historical data, and simulations with the residuals adjustment in which all the balance-sheet items have been set at their trend levels.

version of the MPS model—can then provide further information on the overall magnitude of household balance-sheet effects.

\section{DIRECT, PARTIAL EFFECTS}

Estimates of direct, partial effects of household balance sheets on consumption expenditures for consumer durables and housing starts are presented in table 5. Table 6 converts the results of table 5 into expenditure effects consistent with the concepts of the national income accounts.

Even ignoring the possible amplification by multiplier-accelerator interactions, table 6 shows that changes in the household balance sheet during 1973-75 acted as a powerful depressant on the economy. The balancesheet effects began to have a substantial impact toward the end of 1973, and by the 1975:1 trough, had contributed to a $\$ 37.6$ billion drop in aggregate demand (again, all dollar values are in 1958 prices). To put these simulation results in perspective, the final column of table 6 gives a measure of the recession gap developed by Barry Bosworth, which shows the difference between actual GNP and a level that would have been 
Table 6. Direct, Partial Effects of Household Balance Sheets on Aggregate Demand in Selected NIA Components, and Recession Gap, 1973:1-1975:3

Billions of 1958 dollars

\begin{tabular}{|c|c|c|c|c|}
\hline \multirow[b]{2}{*}{$\begin{array}{l}\text { Year and } \\
\text { quarter }\end{array}$} & \multicolumn{3}{|c|}{ Predicted change in demand } & \multirow[b]{2}{*}{$\begin{array}{l}\text { Total } \\
\text { recession } \\
\text { gapa } \\
(4)\end{array}$} \\
\hline & $\begin{array}{c}\text { Personal } \\
\text { consumption } \\
\text { expenditures } \\
\text { (I) }\end{array}$ & $\begin{array}{l}\text { Housing } \\
\text { expenditures } \\
\text { (2) }\end{array}$ & $\begin{array}{c}\text { Total } \\
\text { (3) }\end{array}$ & \\
\hline 1973:1 & -2.8 & -0.5 & -3.3 & 10.5 \\
\hline 2 & -5.2 & -1.6 & -6.8 & 7.0 \\
\hline 3 & -6.2 & -2.6 & -8.8 & 2.2 \\
\hline 4 & -11.2 & -3.4 & -14.6 & -1.1 \\
\hline 1974:1 & -16.7 & -3.9 & -20.6 & -24.6 \\
\hline 2 & -20.3 & -3.8 & -24.1 & -36.5 \\
\hline 3 & -25.0 & -3.6 & -28.6 & -49.0 \\
\hline 4 & -30.9 & -4.1 & -35.0 & -76.7 \\
\hline $1975: 1$ & -34.0 & -3.6 & -37.6 & -109.4 \\
\hline 2 & -32.7 & -1.9 & -34.6 & -114.6 \\
\hline 3 & -30.3 & 0.3 & -30.0 & -98.7 \\
\hline
\end{tabular}

Source: Simulation results of table 5 converted to expenditures with MPS equations for personal consumption expenditures and housing expenditures. Column 3 is the sum of columns 1 and 2. Detailed procedures are available from the author on request.

a. The measure of the recession gap, developed by Barry Bosworth, equals the difference between actual GNP and the level that would have been achieved had actual GNP maintained the relationship to potential GNP that existed in 1972:4. See Barry Bosworth, "The Stock Market and the Economy," BPEA, 2:1975, p. 290.

achieved had actual GNP maintained the relationship to potential GNP that existed in the fourth quarter of 1972. The 1975:1 figures thus indicate that the direct impact of fluctuations in household balance sheets can account for one-third of the falloff in real aggregate demand during the $1973-75$ recession. ${ }^{42}$

The simulation results in tables 5 and 6 also suggest that in the early stages of the recession, over half of the balance-sheet effects occurred in housing and consumer durables operating through the consumer-liquidity

42. A comparison of these balance-sheet effects with the income effects in regressions for consumption, consumer durables, and housing might put the balance-sheet effects in better perspective. Income effects are obtained from a simulation experiment in which real disposable income after 1972:4 is kept at the same ratio to potential GNP as in 1972:4. The total income effects on expenditure reaches $\$ 33$ billion by the first quarter of 1975 , and this is about 10 percent less than the balancesheet effects estimated above. Because of issues raised in the work mentioned in note 6 , this income-effects simulation must be interpreted with great care, and it is reported here more for comparison purposes than as a guide for policy. 
Table 7. Full-System Effects of Household Balance Sheets on Aggregate Demand, 1973:1-1975:3

Billions of 1958 dollars

\begin{tabular}{rcccc}
\hline & \multicolumn{3}{c}{ Predicted change in demand } & \\
\cline { 2 - 4 } $\begin{array}{c}\text { Year and } \\
\text { quarter }\end{array}$ & $\begin{array}{c}\text { Personal } \\
\text { consumption } \\
\text { expenditures }\end{array}$ & $\begin{array}{c}\text { Housing } \\
\text { expenditures }\end{array}$ & $\begin{array}{c}\text { Total } \\
\text { gross national } \\
\text { product }\end{array}$ & $\begin{array}{c}\text { Total } \\
\text { recession } \\
\text { gap }\end{array}$ \\
\hline $1973: 1$ & -3.0 & -0.5 & -3.0 & 10.5 \\
2 & -5.8 & -1.6 & -8.0 & 7.0 \\
3 & -7.2 & -2.5 & -11.4 & 2.2 \\
4 & -13.0 & -3.2 & -17.5 & -1.1 \\
$1974: 1$ & -19.1 & -3.6 & -25.4 & -24.6 \\
2 & -23.3 & -3.2 & -30.3 & -36.5 \\
3 & -28.6 & -2.7 & -34.8 & -49.0 \\
4 & -35.2 & -2.7 & -40.8 & -76.7 \\
$1975: 1$ & -39.4 & -1.9 & -44.7 & -109.4 \\
2 & -40.2 & 0.1 & -42.2 & -114.6 \\
3 & -38.0 & 2.1 & -32.7 & -98.7 \\
\hline
\end{tabular}

Sources: Results from dynamic simulations starting in 1973:1 using text equations 2,8 and 9 and the full MPS model (all equations have residual adjustments). The balance-sheet items in equations 2,8 , and 9 were set at their trend levels.

a. See table 6 , note $a$.

channel. Net-wealth effects on consumption took longer to build up than did liquidity effects, in part because of the longer stock-market lags in the life-cycle consumption function. They began to dominate liquidity effects by the middle of 1974 .

\section{FULL-SYSTEM EFFECTS}

The experiments with the current version of the MPS model, and with the life-cycle and liquidity equations, provide estimates of the full-system, general-equilibrium impact of household balance-sheet effects. Table 7 reports these estimates.

The effects on the system as a whole are approximately 20 percent larger than the direct effects as a result of multiplier-accelerator interactions, but they display a similar pattern. For the 1973-75 period, the overall effects of household balance-sheet changes on aggregate demand are estimated to be as high as $\$ 44.7$ billion. $^{43}$

43. The multiplier-accelerator amplification of balance-sheet effects is small in this version of the MPS model. An alternative macroeconometric model might lead to even larger full-system balance-sheet effects than are reported here. 
Several conclusions can be drawn from the simulation experiments. The sharp deterioration in household balance sheets indeed appears to have been a major factor in the severity of the economic downturn. The full-system simulations indicate that it was responsible for 40 percent of the depressive effects during the $1973-75$ recession. In the early stages of the recession, liquidity effects were especially important to the decline in aggregate demand as they depressed consumer demand for illiquid assets, consumer durables and housing. Toward the end of the recession, balancesheet effects operated more through net-wealth, life-cycle channels. The simulaton evidence presented here lends credence to the stress on lifecycle and liquidity balance-sheet effects as factors in the economic contraction of 1973-75.

\section{The Stock Market and the 1973-75 Recession}

The link between prices of common stocks and aggregate demand has drawn increasing attention as a research topic in recent years, stimulated by additional evidence that changes in common-stock prices tend to lead business-cycle developments. ${ }^{44}$ Although several investigators concentrate on the behavior of business firms ${ }^{45}$ in studying stock-market effects, the models discussed here present a different view. Movements in commonstock prices tend to be an important factor behind shifts in household balance sheets, and thus the life-cycle and liquidity hypotheses postulate that changes in stock prices can affect aggregate demand by infuencing consumer behavior.

During the 1973-75 recession, which saw the worst bear market since the Great Depression, the impact of the stock market on the household balance sheet was indeed sizable. Over 90 percent of the decline in the real holdings of financial assets from 1973 to 1974 resulted from the drop

44. See Beryl W. Sprinkel, Money and Stock Prices (Irwin, 1964), pp. 115-20, and the literature on leading economic indicators.

45. See James Tobin, "A General Equilibrium Approach to Monetary Theory," Journal of Money, Credit, and Banking, vol. 1 (February 1969), pp. 15-29; John H. Ciccolo, Jr., "Four Essays on Monetary Policy" (Ph.D. dissertation, Yale University, 1975); Charles W. Bischoff, "The Effect of Alternative Lag Distributions," in Gary Fromm, ed., Tax Incentives and Capital Spending (Brookings Institution, 1971), pp. 61-125; and a review of this literature in Bosworth, "Stock Market and the Economy." 
Table 8. Decomposition of Direct, Partial Efiects of Household

Balance Sheets on Aggregate Demand from Debt, and

Nonstock and Stock-Market Assets, 1973:1-1975:3

Predicted change in demand in billions of 1958 dollars

\begin{tabular}{|c|c|c|c|c|c|}
\hline $\begin{array}{l}\text { Year and } \\
\text { quarter }\end{array}$ & $\begin{array}{c}\text { Total } \\
(l)\end{array}$ & $\begin{array}{c}\text { Debt } \\
(2)\end{array}$ & $\begin{array}{l}\text { Nonstock } \\
\text { assets } \\
\text { (3) }\end{array}$ & $\begin{array}{l}\text { Stock- } \\
\text { market } \\
\text { assets } \\
(4)\end{array}$ & $\begin{array}{l}\text { Stock-market } \\
\text { assets including } \\
\text { induced } \\
\text { effects on other } \\
\text { items in the } \\
\text { balance sheet } \\
\text { (5) }\end{array}$ \\
\hline $1973: 1$ & -3.3 & -1.4 & -1.3 & -0.6 & -0.6 \\
\hline 2 & -6.8 & -1.6 & -2.1 & -3.1 & -3.0 \\
\hline 3 & -8.8 & -1.0 & -0.5 & -7.3 & -7.1 \\
\hline 4 & -14.6 & 0.0 & -2.3 & -12.3 & -11.6 \\
\hline $1974: 1$ & -20.6 & 3.1 & -5.3 & -18.4 & -17.0 \\
\hline 2 & -24.1 & 7.2 & -6.6 & -24.7 & -22.4 \\
\hline 3 & -28.6 & 11.1 & -7.4 & -32.3 & -28.7 \\
\hline 4 & -35.0 & 14.2 & -8.6 & -40.6 & -35.6 \\
\hline $1975: 1$ & -37.6 & 16.0 & -8.6 & -45.0 & -38.4 \\
\hline 2 & -34.6 & 17.2 & -7.6 & -44.2 & -36.0 \\
\hline 3 & -30.0 & 18.2 & -6.6 & -41.6 & -32.4 \\
\hline
\end{tabular}

Sources: Column 1 is from table 6 , and is decomposed in columns 2,3 , and 4 . Column 2 gives the simulation results using text equations 2,8 , and 9 , in which liability items are set at their trend values with all other balance-sheet items at historical values. Column 3 gives results of simulations in which the nonstock-asset items are set at their trend values with all other balance-sheet items at historical values. Column 4 gives results of simulations in which the stock-market variable is set at its trend values with all other balance-sheet items at historical values.

Column 5 repeats the experiment of column 4, allowing for induced effects on the other items in the balance sheet by using additional equations to solve endogenously for these other balance-sheet items. Details are available from the author on request.

in the value of common stocks. ${ }^{46}$ Simulations with the life-cycle and liquidity models again provide new information on the size of stockmarket effects during this recession-a subject that has recently been analyzed by Barry Bosworth. ${ }^{47}$ These experiments should also indicate what proportion of the effects that operated through household balance sheets was attributable to the stock market.

Table 8 presents the components of the direct balance-sheet effects of table 6: effects from (1) liabilities, (2) nonstock assets, and (3) stock assets (stemming from each item's deviation from trend). The decline in

46. The real value of household holdings of common stock fell by $\$ 335$ billion from the beginning of 1973 to the end of 1974, versus a $\$ 357$ billion decline in total holdings of real financial assets (1958 prices).

47. Bosworth, "Stock Market and the Economy." 
the real value of liabilities after 1973:4, mostly the result of price increases beneficial to debtors, partially counteracted the depressive effects from the assets side of the balance sheet. Unanticipated price increases, which knocked down the real value of nominally dominated financial assets, were also responsible for the depressive effects from nonstock assets. Stockmarket effects resulted from the combination of a rising price level and a declining nominal view of common stocks.

The stock-market component of the direct balance-sheet effects reaches $\$ 45$ billion (again, 1958 prices) by 1975:1, yet this figure overstates a more appropriately defined effect. When the stock market declines, dampening consumer spending and residential construction as in the models presented here, the other items in the household balance sheet would not remain unchanged, as they do in the simulation experiments of table 8. Purchases of consumer durables and housing are frequently financed by borrowing, and a decline in purchases of these goods induced by the stock market should slow growth of liabilities, thus offsetting some of the depressive stock-market effect. In addition, a fall in consumer spending induced by the stock market will raise the personal saving rate, leading to greater holdings of financial assets, which will also counter the stockmarket effect. Column 5 of table 8 presents simulation results allowing for these induced effects on other items in the balance sheet (by solving endogenously for these items using additional equations). These estimated stock-market effects on household spending are a sizable $\$ 38.4$ billion by 1975:1-less than the column 4 figure because of the induced effects, yet of a magnitude similar to the total direct balance-sheet effects of column 1 .

As the Bosworth discussion emphasizes, changes in prices of common stock might also influence aggregate demand through business fixed investment. ${ }^{48}$ How large are the stock-market effects operating through household balance sheets relative to those operating through investment? The MPS model uses one prominent investment approach in which the stock market affects investment demand through the rental cost of capital. Table 9 contains estimates of direct stock-market effects derived from simulations with the MPS investment sector in which stock-market effects are suppressed by setting the real value of stocks at trend levels. ${ }^{49}$ A com-

48. Ibid.

49. This procedure is used because it is consistent with the earlier stock-market simulations. Here it is assumed that to freeze out stock-market effects, the real value of stocks should be set at trend values regardless of dividend changes. The dividend- 
Table 9. Direct, Partial Stock-Market Effects on Business

Fixed Investment, 1973:1-1975:3

Predicted change in demand in billions of 1958 dollars

\begin{tabular}{rccc}
\hline $\begin{array}{c}\text { Year and } \\
\text { quarter }\end{array}$ & $\begin{array}{c}\text { Investment in } \\
\text { producers' durable } \\
\text { equipment }\end{array}$ & $\begin{array}{c}\text { Investment in } \\
\text { nonresidential } \\
\text { construction }\end{array}$ & Total effects \\
\hline $1973: 1$ & 0.0 & 0.0 & 0.0 \\
2 & 0.0 & 0.0 & 0.0 \\
3 & -0.1 & -0.2 & -0.3 \\
4 & -0.3 & -0.5 & -0.8 \\
$1974: 1$ & -0.7 & -1.0 & -1.7 \\
2 & -1.4 & -1.6 & -3.0 \\
3 & -2.3 & -2.5 & -4.8 \\
4 & -3.5 & -3.7 & -7.2 \\
$1975: 1$ & -5.1 & -5.2 & -10.3 \\
2 & -7.2 & -6.4 & -13.6 \\
3 & -9.7 & -7.1 & -16.8 \\
\hline
\end{tabular}

Source: Results from dynamic simulation experiments starting in 1973:1 using MPS investment sector in which the real value of stock is set at trend values and is used to calculate the dividend-price ratio. The third column is the sum of the first two.

parison of these effects with those of table 8 indicates that the household balance-sheet channels are far more important than investment channels in the transmission of stock-market effects on the economy. In the trough quarter 1975:1, the household effects were over three times the businessinvestment effects, which are very slow in responding because of the long lag structure in the investment equations.

The full MPS model, with additional equations for balance-sheet items and for consumption expenditures and housing, is used in experiments to estimate the general-equilibrium stock-market effects. ${ }^{50}$ The stock-market effects on the full system, operating both through investment and balancesheet channels (given in table 10 ), build up to $\$ 56.5$ billion by the beginning of 1975, indicating that about half of the falloff in aggregate demand

price ratio is then calculated using these trend values. An alternative procedure is to freeze out stock-market effects by fixing the dividend-price ratio at the 1972:4 value. This alternative does not yield very different results: by $1975: 1$, stock-market effects are $\$ 1.3$ billion smaller in absolute value than those of table 9 .

50. Adding equations for balance-sheet items allows for the induced stock-market effects discussed above. 


\section{Table 10. Full-System Stock-Market Effects on Aggregate Demand, and Recession Gap, 1973:1-1975:3 \\ Billions of 1958 dollars}

\begin{tabular}{|c|c|c|c|c|c|}
\hline \multirow[b]{2}{*}{$\begin{array}{l}\text { Year and } \\
\text { quarter }\end{array}$} & \multicolumn{4}{|c|}{ Predicted change in demand } & \multirow[b]{2}{*}{$\begin{array}{c}\text { Total } \\
\text { recession } \\
\text { gap }\end{array}$} \\
\hline & $\begin{array}{c}\text { Personal } \\
\text { consumption } \\
\text { expenditures }\end{array}$ & $\begin{array}{c}\begin{array}{c}\text { Housing } \\
\text { expenditures }\end{array} \\
\end{array}$ & $\begin{array}{l}\text { Business } \\
\text { fixed } \\
\text { investment }\end{array}$ & $\begin{array}{l}\text { Total } \\
\text { GNP }\end{array}$ & \\
\hline $1973: 1$ & -0.5 & -0.1 & 0.0 & -0.5 & 10.5 \\
\hline 2 & -2.4 & -0.8 & -0.2 & -3.1 & 7.0 \\
\hline 3 & -5.7 & -1.9 & -0.8 & -8.3 & 2.2 \\
\hline 4 & -9.5 & -3.1 & -2.0 & -15.0 & -1.1 \\
\hline $1974: 1$ & -14.1 & -4.2 & -3.8 & -22.9 & -24.6 \\
\hline 2 & -18.4 & -5.1 & -6.3 & -30.8 & -36.5 \\
\hline 3 & -23.5 & -6.0 & -9.2 & -39.5 & -49.0 \\
\hline 4 & -28.8 & -6.9 & -12.8 & -49.1 & -76.7 \\
\hline $1975: 1$ & -31.8 & -6.4 & -16.8 & -56.5 & -109.4 \\
\hline 2 & -32.4 & -4.5 & -20.0 & -58.1 & -114.6 \\
\hline 3 & -30.5 & -2.5 & -21.8 & -52.6 & -98.7 \\
\hline
\end{tabular}

Source: Results from dynamic simulation experiments starting in 1973:1 using the balance-sheet consumption expenditures and housing models and the full MPS model, with additional equations for balancesheet items. All equations have residual adjustments. This table gives estimates of the difference between a control simulation and a simulation in which the real value of stocks is set at trend levels. Detailed procedures are available from the author on request.

in the 1973-75 recession can be attributed to the decline in the stock market from trend. ${ }^{51}$

The full-system simulated effects from the stock-market decline can be viewed in a slightly different light. How differently would aggregate demand have behaved in this recession if the stock market had had no adverse influence? In figure 5, the course of real GNP (unrevised data in 1958 dollars as discussed in note 2) in this counterfactual case is compared to the actual movements in GNP. With no stock-market effects, real GNP reaches its peak value three quarters later, and the peak-to-trough decline in real GNP is less than half as severe as it was in fact. Not only would the recession have been of average severity - the percentage decline peak to trough would have been comparable with those in the recessions of 1953-54 and 1957-58 - but by the third quarter of 1975 real GNP would

51. The stock-market effects estimated above are twice those that Bosworth found, primarily because he does not include possible liquidity balance-sheet effects in his experiments. Also, because Bosworth sets the dividend-price ratio at its 1972:4 value in his simulations, the real value of stocks can fall below trend; this results in an understatement of stock-market effects operating through the household balance sheet. 
Figure 5. Comparison of Simulated Path of Real GNP with No StockMarket Effects and Path of Actual Real GNP, 1973:1-1975:3

Billions of 1958 dollars

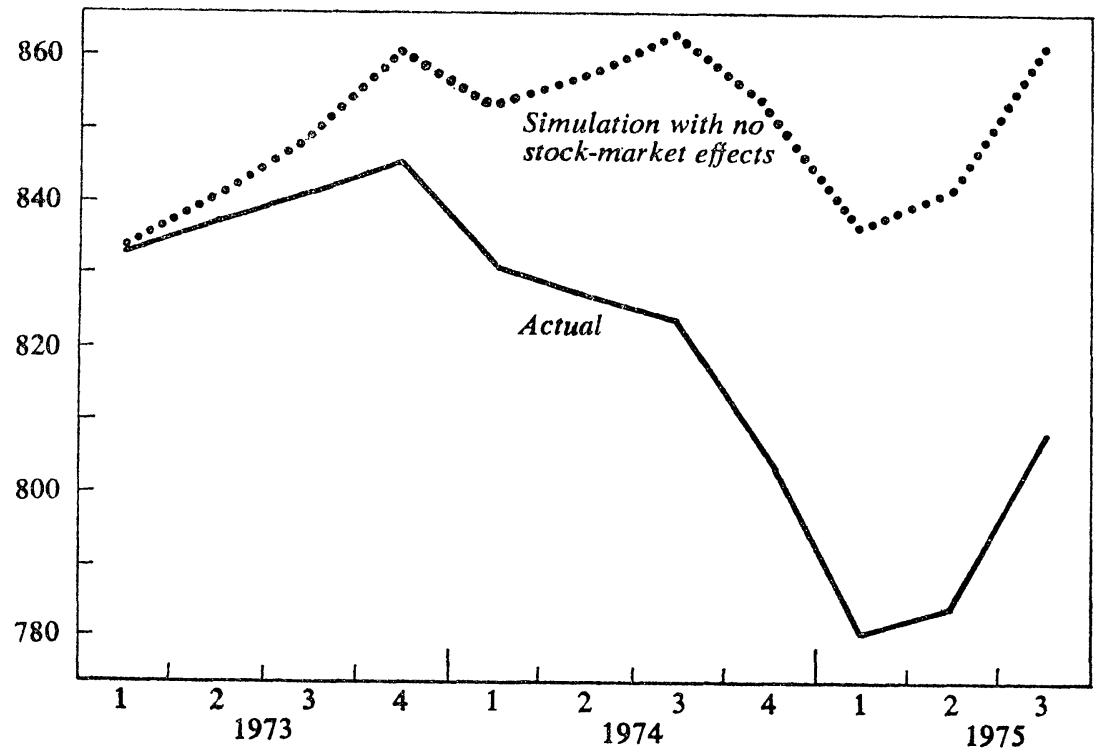

Sources: Simulation results of table 10 , column 4, and U.S. Department of Commerce data before the 1976 revisions of the national income accounts.

have approached its previous peak value. In fact, in the absence of stockmarket effects, the economic downturn would have been far closer to the mild setback that forecasters and policymakers were expecting.

\section{Conclusion}

This paper has attempted to show that changes in the household balance sheet, which were principally the result of the worst decline in prices of common stock in the postwar era, were important depressive forces in the economy. A substantial proportion of the decline in aggregate demand can be attributed to shifts in the aggregate household balance sheet and the depressive effect of the stock market on investment.

Could macroeconomic policy, and in particular monetary policy, have been used to soften the severity of this recession? The answer appears to be "yes." Besides the traditional influence monetary policy has on the 
economy through interest rates, it can affect aggregate demand through the stock market. Much theoretical and empirical research indicates a link between monetary policy and the valuation of common stocks. ${ }^{52}$ Adoption of a more expansionary monetary policy by the Federal Reserve Board, which would have raised the rate of money growth, might have alleviated some of the severity of the downturn. Knowledge of possible household balance-sheet effects on aggregate demand might have convinced the monetary authority that financial forces operating through stock-market effects were extremely depressive, and thus that a more expansionary policy was appropriate.

One moral that emerges from the analysis presented here is that information on the balance-sheet positions of American households should be used in constructing stabilization policies. Furthermore, policymakers should analyze a wider range of monetary phenomena beyond interest rates and the stock of money before embarking on certain policy paths. In particular, movements in prices of common stock should be studied because of their possibly potent effects on aggregate demand.

\section{AP PENDIX}

\section{Variables and Data Sources}

THE FollowiNg variables from the MPS data bank have been described in the text: $C O N, E X P^{C D}, K^{C D}, N, P C D, P C O N, R, S T K, W$, and $Y D$.

Variables from other sources

$$
\begin{aligned}
D= & \text { depreciation rate }=0.02 \text { for single-family housing, } \\
& 0.025 \text { for multifamily housing, and } 0.20 \text { for consumer } \\
& \text { durables. } \\
D E B T= & \text { MPS household-liabilities measure, supplied by the } \\
& \text { Board of Governors of the Federal Reserve System. }
\end{aligned}
$$

52. See Sprinkel, Money and Stock Prices, pp. 115-42; Tobin, "A General Equilibrium Approach to Monetary Theory"; Modigliani, "Monetary Policy and Consumption"; Duncan K. Foley and Miguel Sidrauski, Monetary and Fiscal Policy in a Growing Economy (Macmillan, 1971), pp. 9-85; Richard V. L. Cooper, "Efficient Capital Markets and the Quantity Theory of Money," Journal of Finance, vol. 29 (June 1974), pp. 887-908; Michael S. Rozeff, "Money and Stock Prices: Market Efficiency and the Lag in Effect of Monetary Policy," Journal of Financial Economics, vol. 1 (September 1974), pp. 245-302. 
For the housing equation a mortgage series constructed from seasonally adjusted Federal Reserve flow-of-funds data was subtracted. All the debt measures were deflated by PCON.

$F I N=$ MPS financial-assets measure supplied by the Board of Governors of the Federal Reserve System. The housing equations include the real stock of singlefamily housing, minus the mortgage series described under $D E B T$. The $F I N$ measures were all deflated by PCON.

$H H=$ U.S. households. Annual data are available from U.S. Bureau of the Census, Current Population Reports, P-20, "Population Characteristics." Quarterly interpolations were made using marriage data from U.S. Department of Health, Education, and Welfare, Vital Statistics of the United States, vol. 3, "Marriage and Divorce."

$H S^{S}$ and $H S^{M}=$ single-family and multifamily housing starts, respectively. The variables were constructed in the following manner:

1. From U.S. Bureau of the Census, Construction Reports, C20, "Housing Starts," monthly data were obtained on the number of housing starts in buildings with one, two, three to four, and five or more units. These were seasonally adjusted (with the $\mathrm{X}-11$ program) and compacted to quarterly totals.

2. From U.S. Bureau of the Census, Construction Reports, C40, "Housing Authorized by Building Permits and Public Contracts," data were obtained on the average value per permit in permit-issuing areas. These were blown up using Census estimates of the appropriate factors to give average value per start in permit areas. See U.S. Bureau of the Census, Construction Reports, C30-70S, "Value of New Construction Put in Place, 1958 to 1970," p. 69.

3. Construction Reports, $\mathrm{C} 20$, provided the division of starts between permit and nonpermit areas. For single-family units, the Census Bureau provided an adjustment for average value per nonpermit start, 
$\$ 6,010+0.34$ times the average value per start in permit areas. For units in multifamily structures, nonpermit values were assumed to be 85 percent of permit values. See Construction Reports, C30-70S, p. 69.

4. Average values per start, permit and nonpermit, were then multiplied by their respective number of starts by start class. Values of multifamily starts were the sum of the values for units other than single-family dwellings.

5. The data were then deflated by $P H$.

$K^{S}$ and $K^{M}=$ single-family and multifamily housing stock, respectively. These variables were constructed by using data on the real value of housing starts ( $H S^{S}$ and $H S^{M}$ ) and using weights from H. J. Cassidy and J. Valentini, "A Quarterly Econometric Model of the U.S. Housing, Mortgage and Deposit Markets" (paper presented at the winter meetings of the American Real Estate and Urban Economics Association, 1972; processed), to get completions, blowing completions up by a factor of 1.0581 , and then using this series with a perpetual-inventory method with depreciation rates of 2 percent for single-family houses and 2.5 percent for multifamily houses.

$P H=$ Census price deflator for single-family houses. From U.S. Bureau of the Census, Construction Reports, C30, "Value of New Construction Put in Place."

$Y_{P}=$ expected real average (permanent) income. This was constructed from the MPS data bank series on real disposable income deflated by households $(H H)$ or population $(N)$, using the procedure in Michael $\mathrm{R}$. Darby, "The Allocation of Transitory Income Among Consumers' Assets," American Economic Review, vol. 62 (December 1972), pp. 939-40, with the quarterly adjustment coefficient assumed to be 0.1 as in Darby.

$Y_{T}=$ current disposable income minus permanent income $=Y D-Y_{P}$ 


\section{Comments and Discussion}

Robert J. Gordon: Mishkin presents convincing evidence that equations containing only income and (in the case of durables) the cost of capital cannot explain the collapse of consumer spending in the 1973-75 recession. It is claimed that the explanation that is missing from such equations rests on "changes in the household balance sheet," which constituted an important channel through which "depressive forces" operated on the economy. A further conclusion is that macroeconomic policy, and in particular monetary policy, could "have been used to soften the severity of this recession."

At one level this pair of conclusions represents common knowledge and simply repeats the core of the current macroeconomic consensus taught to many of our students for a decade or more. The second conclusion-that monetary policy can influence consumption through real wealth effects-has been accepted as a theoretical proposition by most economists for more than thirty years. The first conclusion-that real balance-sheet effects matter empirically—seems old hat to aficionados of the MPS model, which has attempted to trace the channels of monetary policy not only through the cost-of-capital variable-already included in Mishkin's "straw man" equations-but also through the direct and indirect effects of the stock market on desired spending.

The most striking piece of evidence that Mishkin's equations reinforce the MPS stock-market results, rather than introducing new channels of monetary influence, is apparent in table 8 . The partial effects of the stock market on household demand (personal consumption expenditures and new housing) exceed the total balance-sheet effects during most of 1974 and 1975. That result holds up even when Mishkin allows for induced effects of the stock market on other balance-sheet items (column 5). It 
raises a puzzle: Why do the balance-sheet effects other than those from the stock market work in the wrong direction? Why is the stock market more than the whole of the total balance-sheet effect?

Thus this paper really is focused on the effect of the stock market on consumption and expenditures on single-family housing. And it raises important questions that bear on its main conclusions:

1. What explains the paradox that balance-sheet effects arising outside the stock market don't matter much and in some cases work perversely?

2. Can one distinguish among three candidates as causes of the collapse in the stock market and hence of expenditures on consumption and single-family housing: (a) monetary policy, Mishkin's implicit candidate; (b) unanticipated inflation, due to the supply-shock and termination-ofcontrols effects documented in my paper; or (c) mysterious lack-of-confidence or animal-spirits effects, due perhaps to inflation or even to Watergate? Retrospective judgment on the wisdom of monetary policy during the recession is sensitive to the choice among these interpretations.

The inconsistency between the in-sample statistical significance of balance-sheet effects apart from those of the stock market and the postsample perverse effects observed in table 8 is partially a reflection of the reduction in real debt brought about by double-digit inflation. Instead of growing at the trend rate of 4.1 percent used in the control solution, real household liabilities decline during much of the simulation period-hence the large positive entries in column 2 of table 8 . The one piece of good news for households was that inflation lightened their real debt burden, and that, according to Mishkin, bolstered their sagging expenditures. But the other side of the inflationary coin was a big negative impact on the real value of nonstock financial assets. The depressive effects on aggregate demand through that channel show up in column 3 of table 8 . These are quite modest relative to the stock-market effects, which reflected both inflation and the sharp fall in nominal stock prices.

The paper raises a related puzzle: Why do the coefficients on nonsotck wealth in the third column of table 4 show up as insignificant in the equations for durables and single-family housing? How could one form of real wealth matter a lot while the other form mattered not at all? The only sensible interpretation I can suggest is that there is no independent real-wealth effect, but rather a "real confidence" effect. Imagine the following example. Currently, 1 percent of all households plan to buy a new car this month, 1 percent the next month, and so on. Now let the nation be 
shocked by an unexpected event-say, an announcement by President Carter that he plans to grow a beard, thus leading to a loss of consumer confidence as the President's mental stability is called into question. Instantly, the stock market incorporates the news and declines; simultaneously, spending plans are revised downward, so that in each successive future month only 0.9 percent of all households plan to buy a new car. Mishkin's equation for durables will estimate a nice distributed-lag relation between spending on durables and the previous behavior of the stock market, but the relationship is not one of cause and effect. Both the stock market and spending have reacted to a third variable, the President's announcement.

The "confidence" or "animal spirits" interpretation of the stock-market coefficients makes me skeptical of Mishkin's policy conclusion-that a more expansive monetary policy could have eliminated the balance-sheet impact on consumption by lifting stock prices. An alternative and equally plausible interpretation is that stock prices went down in 1974 in tandem with the unanticipated burst of double-digit inflation, and that more expansive monetary policy would have both raised current inflation and increased expectations of future inflation, further depressing the stock market and the consumer alike.

One line of defense for Mishkin might be the robust coefficient on the debt variable in table 4, supporting a genuine financial-assets effect. Two problems can be raised here. First, real debt can be moved by a change in either nominal debt or the price level. To what extent does the real-debt variable measure the impact of major changes in the price level and hence in the relationship between inflation and saving behavior to which Juster has called attention on previous occasions? Second, there is the problem of reverse causation which potentially may be more serious. Durable expenditures rely on borrowed funds. Thus the consumer has a relatively low level of indebtedness immediately before buying an automobile and a high level immediately afterward. The negative correlation between previous indebtedness and current purchases would occur automatically for any purchase financed by borrowing even if the level of indebtedness played no causal role.

My final comment concerns table 1 , the tests of alternative creditavailability measures in equations for the real value of single-family housing starts. All of the proxies for the credit-rationing effect appear in table 1 with low levels of statistical significance. This is the most genuinely sur- 
prising result of the paper and conflicts with the MPS-type conventional wisdom regarding disintermediation and housing expenditure. Since any eyeball inspection of the charts in Business Conditions Digest covering saving inflows and housing starts reveals an extremely strong relation, I cannot believe that Mishkin's table 1 tells the entire story. One possible explanation of the insignificant availability coefficients might be the failure to allow distributed lags between saving inflows and the subsequent effect on housing starts. Another might be the long sample period, going back to the 1950 s. I conjecture that similar regressions estimated to the 1960 76 period and allowing for distributed lags would reveal strong availability effects. In light of the widespread closing of the loan windows at many savings institutions in the summer and fall of 1974 , can we really believe that consumers were on their demand curve for housing in that episode?

Saul H. Hymans: It is very easy to begin this discussion of Frederic Mishkin's paper. My overall impression is that it is an excellent one. Having said that, I will, of course, manage a bit of carping criticism. But first, let me indicate why I think so highly of this paper.

Mishkin has produced a model of careful and competent econometric research on a topic of central importance to macroeconomic analysis. The models are formulated with due attention to economic theory and the available literature. Care is taken with the selection and processing of data prior to the fitting of equations. Parameters are estimated with allowances for the underlying stochastic properties of the equations. A number of the likely objections to the specifications adopted are anticipated and given a fair chance; they fail to reject the adopted specifications and are, rather, pretty well dominated by the latter. Finally, the accepted model is put through its paces in simulations that try to shed some light on what happened to the economy in the 1973-75 period.

By 1974:4 consumer durable expenditures were some $\$ 25$ billion (1958 prices) below their peak in 1973:1, and the simulation experiments indicate that about half of that drop can be attributed to the worsening of the consumer's balance-sheet position beginning in 1973. On a more inclusive basis, by the first quarter of 1975 the sum of personal consumption and single-family housing expenditures was depressed by $\$ 37.6$ billion (1958 prices) as a direct result of the worsening of the consumer's balance-sheet position beginning in 1973 . The latter actually exceeds the $\$ 33$ billion (1958 prices) drop in expenditure that a further simulation attributes to 
the shortfall in consumer income beginning in 1973. These are strong implications and it seems that they must be taken seriously.

Let me turn to some worrisome matters now, without meaning to detract from the substantial accomplishments of the paper. I find it difficult to dismiss altogether the possibility that the stock market may be telling us as much about the consumer's willingness to spend-that is, consumer sentiment-as it is about the consumer's ability to spend. It is well known that stock-market developments are an important predictor of the index of consumer sentiment, and one could plausibly infer that the power of the stock variable derives partly from its being a proxy for consumer sentiment. The paper provides conflicting indirect evidence on this issue. Consumer sentiment is best predicted by roughly contemporaneous movements in the stock market, not by a long distributed lag on stock prices. Yet the distributed lag is generally a bit stronger in Mishkin's equations than an unlagged measure of stock holdings, a point in favor of the wealth interpretation. Further, if the stock variable is, in part, a proxy for consumer sentiment, there would be little reason to expect stock and nonstock wealth to have the same effect on consumer spending; yet Mishkin is unable to reject this "assets constraint." On the other hand, the equations for durables fail to produce a significantly nonzero coefficient on nonstock wealth in the absence of the assets constraint, and the durables equation is the very one in which consumer sentiment is most likely to play a role. Mishkin indicates that the consumption equation rejects consumer sentiment in the presence of the wealth variables, but he makes no mention of any direct test of the sentiment variable as a substitute for wealth in connection with the durables equation. And for what it's worth, a plot of the time series of the consumer sentiment index looks very much like the net worth series in figure 1 and the durables expenditure series in figure 3. Although this issue worries me a bit, I am beginning to feel that perhaps we had better stop blaming the stock market for its correlation with the index of consumer sentiment. After all, the theory supporting the wealth effect on aggregate demand is very compelling.

For the rest of my comments, then, let me beg this spurious-correlation problem and grant that the stock variable has its primary role as a wealth component-even though my conviction on the matter hasn't quite the purity of driven snow, much less Ivory Snow.

Some time ago I investigated the effects of wealth and stock-market variables on consumption (BPEA, 1:1970) and concluded that they were 
no panacea. At that time I suggested that the use of stock-market variables did little more than shift the dating of one's forecast errors. I still think so. Although they helped Mishkin a good deal with an impressive postsample explanation of 1973-75, let me remind you that 1954, 1956, and 1961 were boom years for common stock prices and quite bad years for consumer durable expenditures. Similarly, 1953, 1962, and 1966 were very bad years for common stock prices and excellent years for consumer durable purchases. And in the same vein, I would caution Mishkin against viewing the stock-price index as a reliable leading economic indicator. In my study of the leading indicators (BPEA, 2:1973) I took a special look at the stock-price component of the composite index of leading indicators. The inference I drew was that stock prices were a major contributor to the tendency of the composite index to provide false-peak signals. Using spectrum-analytic techniques, I found that stock prices displayed a good deal of high-frequency power which had poor coherence with respect to the less substantial high-frequency power in the general business cycle.

On the other hand, I don't want to push this line of analysis too far. Mishkin's approach is that of estimating a multivariate structural equation which derives from prior considerations of economic theory. In that context, it is somewhat unfair to criticize a single part of such an equation for being unable to predict adequately by itself. Certainly, the stock market by itself produces false signals; but so does current income and nobody is seriously questioning the proper place of income in a consumption equation. If we were in the habit of using only balance-sheet and price variables in consumption equations and it were suggested that current income be included as well, someone would undoubtedly object that income is no panacea: it just shifts the dating of one's forecast errors. And then someone else would come along and invent some funny distributed lag in income to filter out the false signals.

Next, how much better off are we as forecasters knowing that balancesheet considerations are important if that leaves us having to forecast the balance-sheet items? I suspect we can handle the forecasting of various debt components and nonequity assets, but what do we do about stock prices? Perhaps we can benefit from the finding that stock prices affect consumption with a distributed lag, and focus attention directly on the explanation of such a smoothed or filtered index of stock prices.

Finally, I wonder whether it might not be possible to improve matters by disaggregating a bit further. My work on the Michigan model indicates 
that there is mileage in disaggregating consumer durables into three or more categories and that nondurables and services can also be separated profitably. And speaking of disaggregation, I'd feel a bit better about my conversion to respectful agnosticism if I knew what happened to Mishkin's equations in a pre- and post-1965 split of the sample period. Barry Bosworth, in his paper on the stock market (BPEA, 2:1975), found some significant differences according to whether the data period included the post-1965 experience. This test might be as strong and revealing as the specification tests that Mishkin ran on his fixed sample period.

None of us who have ever hesitated to buy another big-ticket item on credit can really deny that balance-sheet items ought to matter. And people do "take gas" when the stock market plunges, and buy haciendas with swimming pools when stock values climb. The real issue has always been whether these effects are of aggregative importance and how best to measure them. Despite the qualms already expressed, I suggest that Mishkin has made an important contribution to our knowledge about whether and how the consumer's balance sheet affects the aggregate economy.

Frederic S. Mishkin: Both Gordon and Hymans raise the possibility that stock-market effects are just proxies for consumer sentiment or, alternatively, for the appearance of new, unexpected information that affects consumer behavior and the stock market simultaneously. One hint that stock-market effects stem from balance-sheet considerations and are thus structural is the finding of a significant coefficient on the debt variable in consumer durables and housing equations. The existence of debt effects cannot be explained away by Gordon's suggestion that the debt variable may be a proxy for inflation effects, since unanticipated inflation leads to lower real indebtedness; this implies a positive debt coefficient if inflation has a depressive effect on consumer expenditure, as in Juster's view, rather than the negative coefficient implied by the liquidity hypothesis. Nor can debt be a proxy for a stock-adjustment effect, since a lagged stock term that captures this effect is included in both the housing and consumer durables equations, and yet the debt variable still retains its significant coefficient.

Both Gordon and Hymans mention the results on nonstock assets in the consumer durables and housing equations-one to support and one to question the existence of balance-sheet effects on these sectors. In fact, there isn't much that we can say about the size of nonstock-asset effects 
on the basis of my statistical results. The small variation of the nonstockassets variable, possibly a result of the procedure for measuring this variable, leads to a large standard error of the variable's coefficient which does not allow much distinction among competing hypotheses.

\section{General Discussion}

Several panel members joined Gordon and Hymans in suggesting that the stock-market variable in Mishkin's equations might be acting as a proxy for other, omitted, variables. Benjamin Friedman, Michael Wachter, and Thomas Juster all felt that the estimated marginal propensity to consume out of equities was implausibly high, given the degree of concentration of U.S. stock-market holdings. Friedman noted that most equities either are held by the very rich, whose consumption behavior is not likely to be closely tied to wealth, or are owned indirectly through pension funds and insurance companies, where they are similarly unlikely to exert much influence on consumption. He suggested that Mishkin has to rely on too few consumers to explain the changes in consumer durable purchases by changes in stock-market wealth. Mishkin responded that concentration of stock-market assets in the hands of the rich does not have to result in small stock-market effects. He cited in support the recent Friend and Lieberman cross-section study of the effects of capital gains, and suggested that, according to their results, stock-market effects might be even larger than those found in this paper. He argued, furthermore, that in a cross-section these effects cannot stem from omitted variables such as consumer sentiment or the presence of new, unexpected information. Friedman also pointed out that the changing valuation of the housing stock, the largest and most widely distributed component of private wealth, is not reflected in the wealth total used by Mishkin.

Juster argued that "animal spirits" - in this case, feelings of uncertainty about future income-were the most important determinant of consumer durable purchases. He reported that an equation using the consumer sentiment index tracked the 1973-75 period extremely well. Mishkin replied that when he had tried a consumer sentiment variable in both the housing and consumer durable equations, it was rarely significant and had not changed the estimates of the stock-market effects. He observed that it was really not possible to distinguish between the theories of con- 
sumption behavior by examining the consumer sentiment variable. Both his theory, which incorporates the fear of financial distress, and the lifecycle theory, which is based on expected lifetime income, allowed a role for consumer sentiment.

Christopher Sims found it inappropriate to try to choose between a stock-market variable and a consumer-sentiment variable on the basis of how well they track movements in expenditure components. What really matters is whether a balance-sheet relation like Mishkin's is identifiable and stable under variations in policy. This could be true even if consumer sentiment, via another relation in the system, tracked expenditures very well. On the other hand, no level of tracking performance is good enough to guarantee that Mishkin's relations are reliably identified. Both the balance-sheet situation and consumer sentiment are endogenously determined. The crucial question is whether the endogenous variables are related in a reliable fashion, regardless of what things change. Sims felt that this element dictated great care in the choice of instruments to correct for simultaneity bias, and he called for explicit tests of the exogeneity of the instrumental variables Mishkin had used.

George Perry observed that, since the stock market is the major source of short-run changes in wealth, the criticisms of Mishkin's use of the stockmarket variable really apply to all consumption equations that use net wealth-even if they do not separate the stock-market component. Mishkin agreed and stressed that the data on assets other than stocks, which were calculated from flow-of-funds data, exhibited little short-run variability since revaluations are ignored, thus making it difficult to obtain precise estimates of nonstock-asset effects in equations for consumer durables and housing. They had therefore been constrained to have the same coefficient as the stock-market assets. Franco Modigliani said that the constraint that the marginal propensities to consume from all types of wealth be equal had been imposed on the original MPS consumption equation because, at the time, it had been incorrectly thought that the life-cycle approach did not allow for differences among income classes in consumption behavior. Later extensions of the theory recognized the bequest motive as a source of such differences. Hence, if the stock market assets are owned disproportionately by higher-income households, the marginal propensity to consume out of equities might well be lower than that out of other wealth.

Stephen Goldfeld believed that Mishkin had implied too mechanistic a 
link between monetary policy and stock-market prices. The full implication of Mishkin's policy discussion was that the Federal Reserve ought to engage in open market operations in equities-a policy recommendation that Modigliani suggested might well be worth consideration. Mishkin stated that he did not intend to imply a mechanistic link between monetary policy and stock-market prices, especially because the effect of monetary policy on stock prices is critically dependent on expectations as to Federal Reserve actions. These considerations might make control of common stock prices through open market operations an extremely tricky task.

Some improvements in the specifications of the equations were suggested. Goldfeld remarked that, in recent years, the widespread provision of overdraft facilities might have reduced the necessity to liquidate durables in times of consumer distress. He urged that this effect be tested and, if important, taken into account. Juster suggested adjusting the stock of consumer liabilities for the trend toward longer contract maturities since Mishkin's theory is really based upon the size of the flow of consumer commitments. Juster also preferred that the variables be expressed in per household rather than per capita terms. 